\title{
Reconstructing past terrace fields in the Pyrenees: Insights into land management and settlement from the Bronze Age to the Early Modern era at Vilalta (1650 masl, Cerdagne, France)
}

\author{
Christine Rendu ${ }^{1}$, Olivier Passarrius ${ }^{2}$, Carine Calastrenc ${ }^{1}$, Ramon Julia ${ }^{3}$, \\ Murie Llubes ${ }^{1}$, Pauline Illes ${ }^{2}$, Pierre Campmajo ${ }^{1}$, Clara Jodry ${ }^{1}$, Denis Crabol ${ }^{4}$, \\ Elisabeth Bille ${ }^{1}$, Marc Conesa ${ }^{5}$, Delphine Bousquet ${ }^{1}$, Véronique Lallemand ${ }^{6}$
}

${ }^{1}$ CNRS and University of Toulouse, France, ${ }^{2}$ Archaeology Center of the Pyrénées-Orientales Department and University of Perpignan, France, ${ }^{3}$ Institute of Earth Sciences Jaume Almera, CSIC, Barcelona, Spain, ${ }^{4}$ Archaeological and Historical Research Group of Cerdagne (GRAHC), Bourg-Madame, France, ${ }^{5}$ University of Montpellier, France, ${ }^{6}$ Regional Archaeology Department of Languedoc-Roussillon, French Ministry of Culture

The building of a solar power station at Thémis, at 1650 masl on the south-facing slope of the Carlit massif in the eastern Pyrenees, led to an archaeological evaluation from April-June 2009. This evaluation covered a surface of 10 ha that included a medieval village as well as the surrounding agricultural land in terraces. Non-destructive archaeological methods were used for the village. A detailed study of the 6 ha of terraces began with a fieldwalking survey, mapping every visible feature, followed by systematic trial trenches. Fifty-five trenches, 11 in the village and 44 in the fields, were opened. The stratigraphies were then compared with a series of 22 radiocarbon dates and eight relative dates provided by ceramic typologies. This combination of surface and buried evidence supported our preliminary hypothesis about the dynamics of the slope. The results suggest the existence of agrarian features beginning in the Bronze Age and reveal that the field patterns were frequently transformed, both in the Medieval and Early Modern periods. The transformations in the terrace fields after the village was abandoned are as interesting as those during occupation because, contrary to the idea of a fixed, unchanging landscape after the end of the Middle Ages, they challenge the idea that mountain zones are marginal spaces by nature, or were marginalized later.

Keywords: landscape archaeology, mountain, terrace, settlement, offsite dating

\section{Introduction}

Mountain slopes have rarely been subjected to large construction projects. Therefore, archaeological observations on changes in the soil and the landscape in mountain zones are most often the result of chance, limited excavations, or test pits. In 2009, the project to extend the solar power plant at Thémis threatened an abandoned medieval village that had been discovered during the power plant's construction (Campmajo 1979). The presence of this village, named Vilalta, led to an archaeological evaluation of the area, which covers 10 ha ranging at 1600-1700 masl. This site

Correspondence to: Christine Rendu, Laboratoire Framespa, Maison de la Recherche, Université de Toulouse II, 5 allées A. Machado, 31058 Toulouse Cedex 09, France. Email: rendu @univ-tlse2.fr assessment included not only the village but also nearly 6 ha of terraced fields nearby.

The first goal of any assessment is to estimate the archaeological potential of the area in order to decide whether or not to move forward with an open-air excavation and to estimate the costs and duration of such a study. Evaluations are thus usually rapid and brief: surface surveys are rare, and excavation and detailed analysis of structures are usually excluded, as well as dating them by any means other than with archaeological artifacts. Generally, the protocol is to mechanically open $10 \%$ of the surface area, with large trenches spaced at regular intervals.

Yet, the Thémis site evaluation took place in a particular scientific context, which enabled us to combine trench protocol with other methods used in 
more long-term archaeological research. Of all the zones in the Pyrenees range, the micro-region in which the site is located (in the Cerdagne massif in the eastern Pyrenees) has been a particularly important area for examining the dynamics of space and landscapes at altitude over the long term (Campmajo 1991; Davasse et al. 1997; Galop 1998; Rendu 2001, 2003; Ruas et al. 2005; Bréhard and Campmajo 2005; Bal et al. 2010; Bousquet 2011). Thus, the archaeologists responsible for the rescue evaluation and those archaeologists involved in the long-term research program worked together to study this landscape with complementary approaches: a field survey of all surface features preceded the opening of trial trenches; the trenches were planned to follow an altitudinal transect; when possible, buried features were excavated; and a large number of radiocarbon dates were collected, mostly in terrace contexts which is rare, as terraces generally have very few dating elements.

The main purpose of this article is to present the methods and the results of this archaeological evaluation and to assess the results within the broader perspective of a history of mountain landscapes. Combining methods enabled us to compare a large number of stratigraphies and to understand the morphological dynamics of terrace systems within a relatively continuous area, which is fairly rare. Based on the considerable number of dates obtained, the goal was also to contribute to research on terrace systems in other regions, such as in South America (Sandor and Eash 1991, 1995; Sandor 2006; Kemp et al. 2006; Borejsza et al. 2008; Acabado 2010) and in the Mediterranean (Bal 2006; Ballesteros Arias 2006, 2010; Harfouche 2007; Riera and Palet 2008; Frederick and Krahtopoulou 2008; Quiros Castillo 2009; Bal et al. 2010; Bevan et al. 2013; Davidovich et al. 2012). Thus, we also discuss the chronological relevance of the elements dated within the stratigraphies (see below).

These results enabled us to reconstruct the dynamics of the landscape over the long term. They are discussed below by period, re-situated in the broader regional context. Several issues that are essential for understanding mountain spaces are addressed: the importance of agrarian features in the organization of slopes; their flexibility and adaptability, which reveal considerable sensitivity to socio-environmental changes; and the influence of broader socioeconomic factors on these changes, challenging the idea that mountain spaces are by nature marginal.

\section{Site and Methods}

\section{The Vilalta site and its environment}

In the eastern Pyrenees, the Cerdagne is a large intramountain plateau, $80 \mathrm{~km}$ long and oriented northeast-southwest, corresponding to the basin of the Segre River, a tributary of the Ebro River (FIG. 1). It has a Mediterranean climate with an average

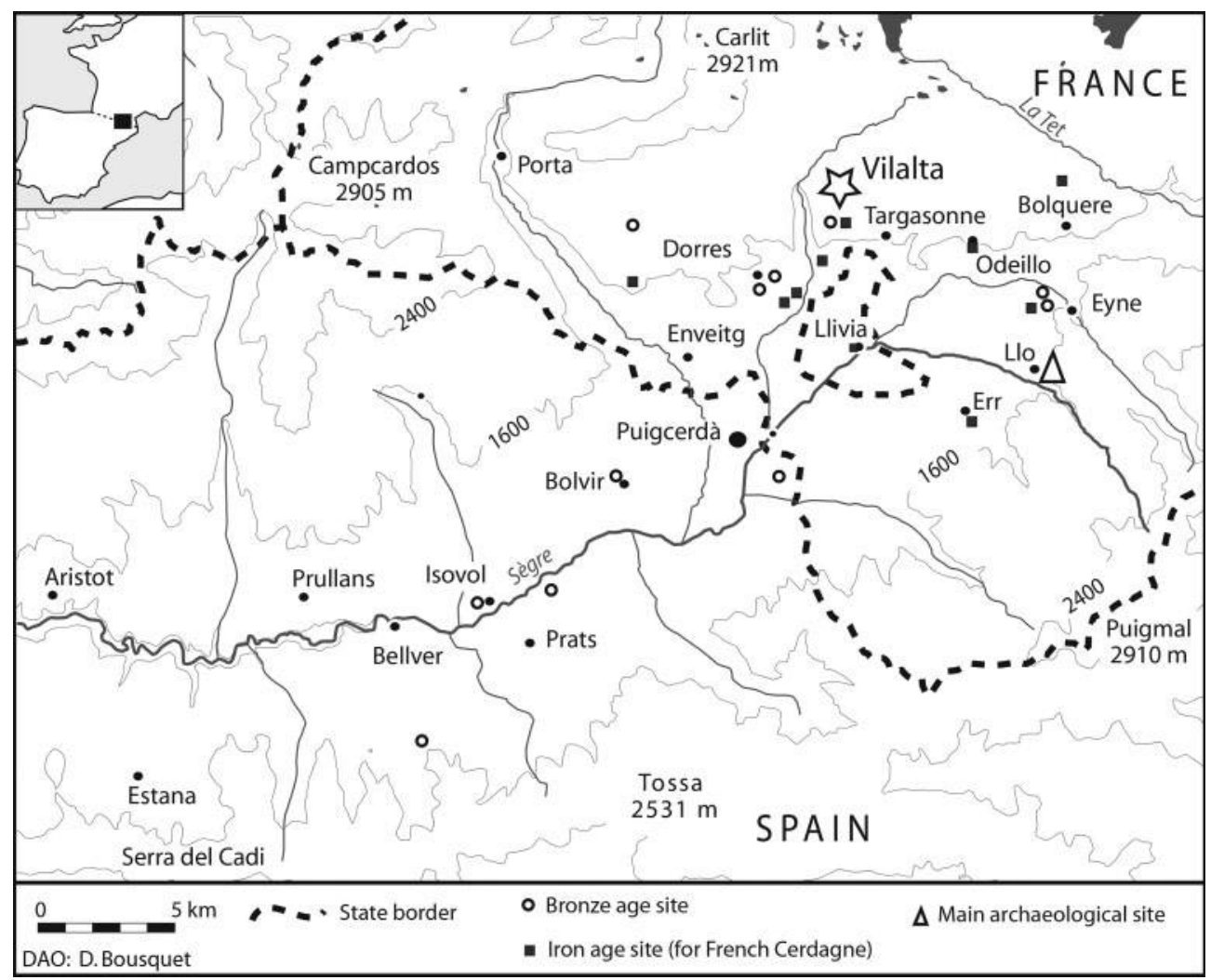

Figure 1 Location of the Vilalta site in Cerdagne, eastern Pyrenees. 
altitude of $1100 \mathrm{~m}$ and is bounded on the north and south by massifs reaching $3000 \mathrm{~m}$. The site ranges from $1600-1700 \mathrm{~m}$ in altitude on the south-facing slope of the Carlit massif.

The zone is primarily formed by the Mont-Louis granitic massif (Maurel et al. 2002), with a complex geological history marked by the presence of old erosion surfaces and features resulting from the last ice ages. The former village of Vilalta is located at the heart of a large flat area that is Tertiary in age (Calvet and Gunell 2008; Delmas et al. 2009). It is bounded by four geomorphological units (FIGS. 2.1, 2.2): in the west by the Angoustrine lateral moraine formed by a thick till deposit of granite boulders in an orange sandy matrix with the occasional presence of bluish silty clay; in the east by a small alluvial fan characterized by dark sandy sediments mixed with gravel and occasional boulders; towards the north by the granite slope, with slope deposits characterized by weak soil development and the occasional emergence of the granite substrate; and towards the south, by the Targasonne granite boulders.

The vegetation is that of the subalpine zone. Above the site, at over 2000 masl around the first shepherds' cabins, there are woody areas of Pinus uncinata and grazing pastures with Festuca gautieri, Deschampsia flexuosa, and Trifolium alpinum. Below that, at around 1700 masl, a wood of Pinus sylvestris
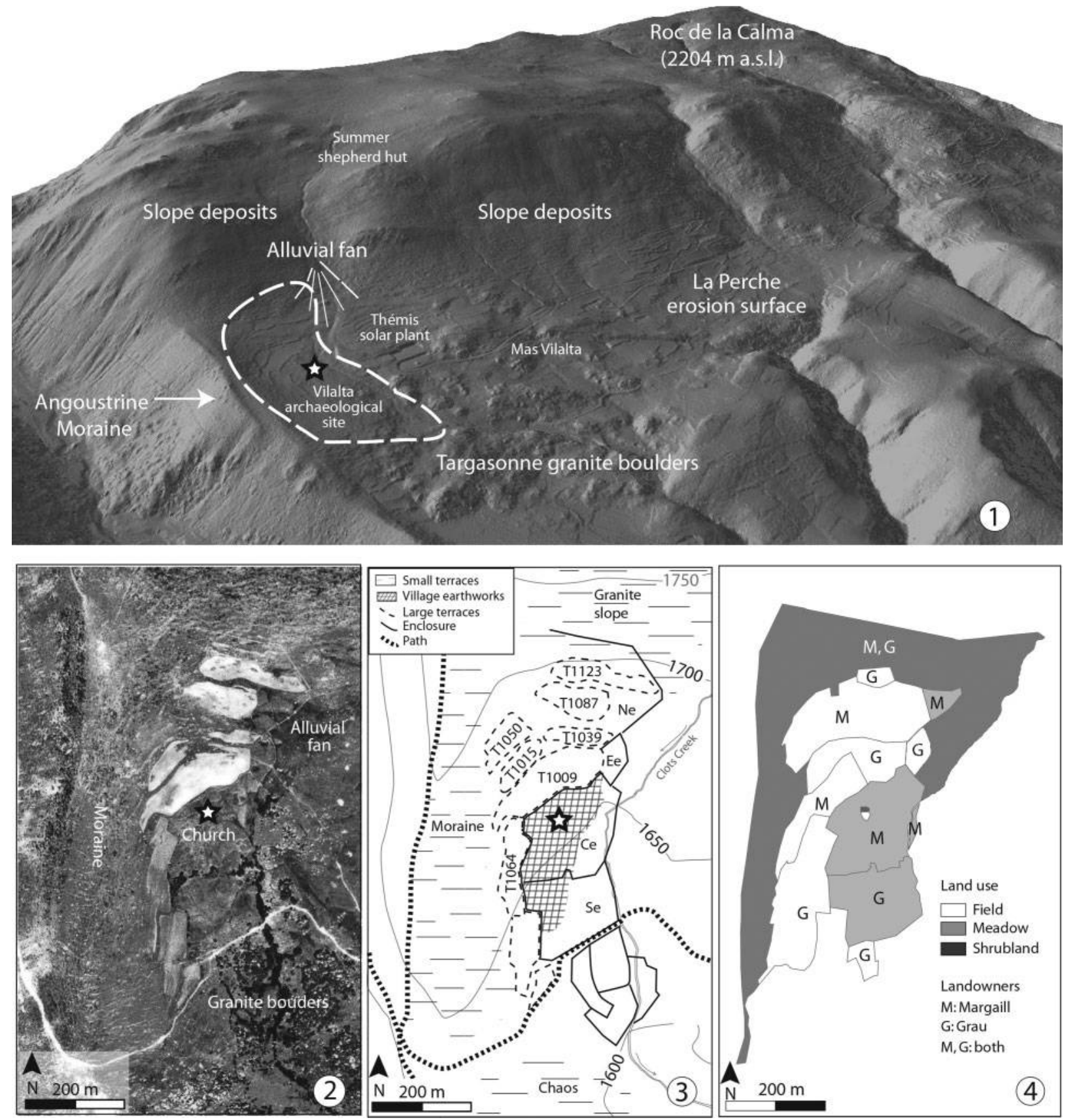

Figure 2 Geomorphological and human landscape. 1) Geomorphological context (the star indicates the church); 2) Aerial photograph from 1977 (courtesy of Compania Espanola de Trabajos Fotogrametricos Aereos collection); 3) Field system; 4) Landowners and land uses on the cadastral map of 1829. 
I uncinata occupies the crest of the moraine and a dry shrubland of Cytisus purgans, Juniperus communis, and Rosa canina covers the main part of the slope. Below this area are the former terraced fields, then the irrigated and enclosed meadows. The tree vegetation here is composed of Alnus glutinosa bordering the stream and a few willow, poplar, birch, aspen, and ash trees. The granite boulder landscape is primarily covered with hazelnut trees that re-colonized the area during the 20th century.

The medieval village is located at the center of this space, in an enclosed meadow at the foot of the terraces (FIGS. 2.2, 2.3). It is perceptible only by the presence of earthworks and some ruins of a Romanesque church. The terraces occupy the entire side of the moraine and extend up to the middle of the granite slope. The terraces are of two kinds. The lowest ones (T1064, T1009, T1015, T1050, T1039, T1087, and T1123) are large, ranging from 0.5 to 1.5 ha in size with earthbanks from 1.5 to $4 \mathrm{~m}$ high. All of the larger terraces were cultivated and worked until the 1970s and the three lowest in altitude, accessible to tractors, are still worked today (rye and potatoes). They contrast strongly with the second kind: narrow and eroded terraces that are above them on the moraine and the slope (FIG. 2.3). These narrow terraces have been abandoned. There are also four drystone walled enclosures. The two largest ones-enclosures Center (Ce) and South (Se) - are below the terraces. Their dimensions are almost identical (4 ha) and may have resulted from the division of a single original plot. These are irrigated meadows that are still today mowed and then used as pasture for horses and cattle. The third enclosure, on the east (Ee), is smaller and diamond shaped, and finally there is the North Enclosure ( $\mathrm{Ne}$ ), whose walls are conserved only on its eastern and northern sections and which partially enclose the large terraces above.

Historical evidence for this area remains rare. The parish of Saint Vincent of Vilalta appeared for the first time in the written sources in 1163 (Marca 1688: col. 1335) in a papal bull which confirmed all the lands the Abbey of Saint Martin-du-Canigou had in the area. We also know this abbey had held lands in the area since 1035 (Alart 1874: 32). The parish then appeared in documents of pastoral visits until 1391, in particular documents dealing with tithes. In 1359, there were four tax hearths registered and by 1497, none at all (Batlle and Gual 1973). In 1591, the area was no longer called "parrochia" or "vila" of Vilalta, but rather by the name of "Mas Vilalta" (Bosom and Vela 2009: 352). This term perhaps indicates that the current hamlet called Mas Vilalta, which is $800 \mathrm{~m}$ southeast of the medieval village (FIG. 2.1), had become the main center of habitation. At the beginning of the 19th century, according to the earliest extant cadastral map (dated 1829), this hamlet was composed of two mas (rural estates) that possessed the totality of the plots in the area examined in this study. The fact that ownership of these parcels alternated between the two mas, and the indivisible possession of the plots of land located uphill on the slope, may indicate a patrimony with a common origin (FIG. 2.4)

\section{Methods for archaeological assessment}

The rescue archaeology zone covered 9.75 ha, divided into the 4 ha of the $\mathrm{Ce}$, in which most of the village is located, and a little less than 6 ha of land above it on the slope. Two partially different survey strategies were applied to these two zones.

For the village, the French Ministry of Culture's wish to preserve the features led to the use of a combination of non-invasive methods: a systematic field survey with a DGPS recording of all the features observed, an electrical resistivity survey, a magnetic survey, and the study of aerial photos. Combining these various data in a GIS enabled us to produce a predictive model of the presence of buried features and to limit the number of trial trenches to 11 , with a reduced total area (244 sq $\mathrm{m})$. The choice of trench location was carefully considered with regard to the survey data, in order to have the least impact on the remaining structures. The purpose of the trenches was to verify the accuracy of the observations made during the initial survey phase, to clarify the state of site preservation, to evaluate the thickness of the stratigraphy and the complexity of construction, as well as to refine the dating of the creation and abandonment of the village.

The study of the 6 ha began with a DGPS survey and recording of every surface feature, whether still functional today or abandoned. The dimensions of the features, the materials used, and their degree of preservation were recorded in attribute tables. We also noted running joints (clean breaks in walls where they had been rebuilt or repaired) and reworking of walls, terrace retaining walls and earthbanks, and the presence of stones that indicated traces of dismantled walls. All of this data, as well as traces observed in aerial photos and the limits of plots from the 1829 cadastral map and those of the current cadastral map, were entered into the GIS. Forty-four trial trenches were then dug in this zone, opening rate approximately $5 \%$ (FIGS. 3,4). The sedimentary profiles were studied in 30 stratigraphic profiles. Certain features were cleaned out more deeply, and deep double floor (stepped) trenches were dug in certain sections, reaching a depth of approximately $2.5 \mathrm{~m}$. Buried archaeological features were manually cleaned as much as possible. The natural bedrock was reached almost everywhere except on the lowest terrace, also 
the deepest. A final topographic map of the features and the trenches was created and integrated into the GIS (FIG. 3).

Twenty-two radiocarbon analyses were conducted by the Beta Analytic laboratory on charcoal particles taken from the profiles or the features. The calibration curve used was IntCa109.14c (Reimer et al. 2009). The relative scarcity of material did not enable us to choose bark or branches, and thus we cannot exclude an old wood effect on certain dates. Eight other relative dates were provided by the types of ceramics found on site. The dates in this paper are in TABLE 1.

\section{Results}

The Village: Layout and chronology

Although the buildings' functions and a precise chronology of habitation are impossible to establish at this stage, the correlations between the surface surveys, the trial trenches, and stratigraphic observations enabled us to reconstruct an overall picture of the spatial organization of the village. The village, in which about 90 built units, gathered in clusters, were found, is open and organized along both sides of a north-south path, at the end of which is the church and the cemetery. In the western part (FIG. 3: a), construction is dense and is at multiple stories on the slope. In the east, after a first row of buildings, tightly together and bordering the path, the spacing of the buildings behind becomes more spread out. The large outlying buildings (FIG. 3: b, c, d), which appear to mark the transition between the village and agricultural space, may correspond to barns or stables. However, we do not know the western limits of the village, which appears to have been covered over by T1064.

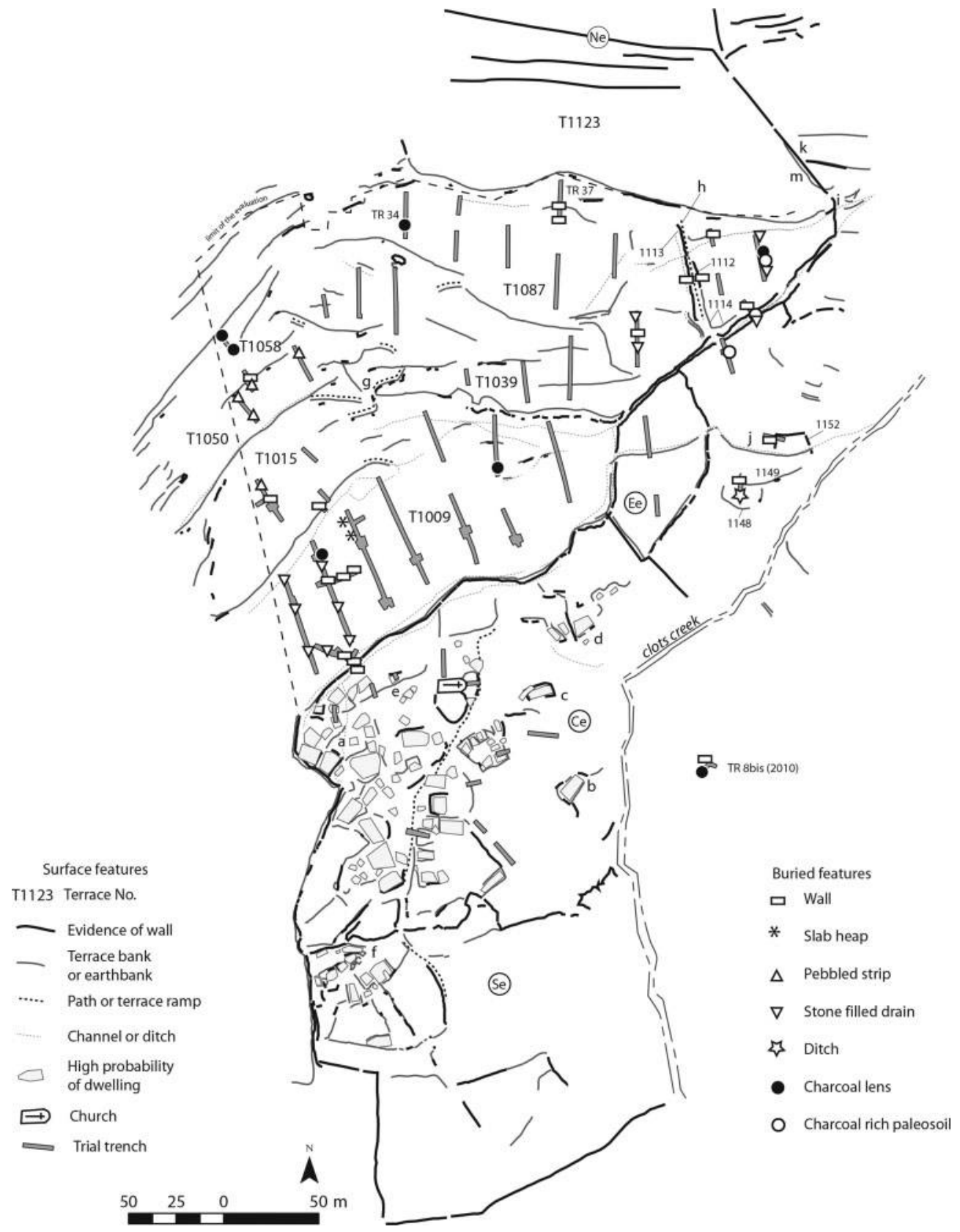

Figure 3 DGPS surface survey results of the total area surveyed, with the locations of buried structures in the trial trenches. 
Table 1 Radiocarbon and ceramic-based dates from the Vilalta excavations (in chronological order). The radiocarbon dates are in regular characters (a minus sign signifies B.c.), dates from pottery typologies are in italics. The calibration curve used was IntCal 09 (Reimer et al. 2009).

\begin{tabular}{|c|c|c|c|c|c|c|c|}
\hline Date No. & Trench & Sample no. & Stratigraphic context & Lab Code Beta & 14C Age & \pm & $\begin{array}{l}\text { Age cal A.D./B.C. } \\
\text { ( } 2 \text { sigmas) }\end{array}$ \\
\hline 1 & 34 & VIL 6.2 & $\begin{array}{l}\text { Charcoal lens in the section, infilling } \\
\text { of an ancient natural hollow }\end{array}$ & 265272 & 5760 & 50 & $-4721-4491$ \\
\hline 2 & 47 & Layer C & $\begin{array}{l}\text { Charcoal-rich layer of coarse altered } \\
\text { granite } \\
\text { sand (base of the profile) }\end{array}$ & 264720 & 4910 & 40 & $-3771-3640$ \\
\hline 3 & 46 & 2023 & $\begin{array}{l}\text { Charcoal-rich pit in the altered granite } \\
\text { sand (base of the profile) }\end{array}$ & 264718 & 4840 & 40 & $-3703-3526$ \\
\hline 4 & 13 & VIL 4.6 & Layer underlying unit 2004 & 265272 & 4730 & 40 & $-3635-3376$ \\
\hline 5 & 14 & $14 \mathrm{~W} 1$ & $\begin{array}{l}\text { Charcoal-rich layer underlying wall } \\
2001 \\
\text { (in physical contact with wall stones) }\end{array}$ & 264716 & 3170 & 40 & $-1521-1383$ \\
\hline 6 & 13 & VIL 4.5 & $\begin{array}{l}\text { Layer of unit } 2004 \text {, below the } \\
\text { coarse gravel channel }\end{array}$ & 265271 & 3140 & 40 & $-1499-1314$ \\
\hline 7 & 22 & 2007D & $\begin{array}{l}\text { Organic layer D, retained by stones } \\
\text { of wall } 2007\end{array}$ & 264712 & 3030 & 40 & $-1407-1191$ \\
\hline 8 & 22 & $2007 \mathrm{~A}$ & Reddish sand underlying wall 2007 & 264713 & 3000 & 40 & $-1386-1123$ \\
\hline 9 & 42 & Layer C & $\begin{array}{l}\text { Compact soil interstratified with sandy } \\
\text { channels }\end{array}$ & & & & $-1000-700$ \\
\hline 10 & 49 & Ditch 2026 & In the ditch fill & & & & $100-400$ \\
\hline 11 & 42 & Layer C & $\begin{array}{l}\text { Compact soil interstratified with sandy } \\
\text { channels }\end{array}$ & 264708 & 1540 & 40 & $426-600$ \\
\hline 12 & 49 & Ditch 2026 & In the ditch fill & 264717 & 1380 & 40 & $582-694$ \\
\hline 13 & 12 & SU 122 & $\begin{array}{l}\text { Charcoal lens } 30 \mathrm{~cm} \text { large, at } \\
0.8 \mathrm{~m} \text { deep }\end{array}$ & 264715 & 1270 & 40 & $662-828$ \\
\hline 14 & 55 & B & $\begin{array}{l}\text { Brown silty layer with organic matter, } \\
1.3 \text { to } 2.5 \mathrm{~m} \text { deep below terrace wall } \\
129\end{array}$ & 282087 & 1240 & 40 & 680- 882 \\
\hline 15 & 8bis (2010) & SU 3 & $\begin{array}{l}\text { Earth in a soil containing charcoal } \\
\text { and ceramics (dwelling occupation } \\
\text { layer?) }\end{array}$ & 287382 & 1150 & 40 & $778-980$ \\
\hline 16 & 37 & 2030 & $\begin{array}{l}\text { Sandy silt layer, } 0.2 \mathrm{~m} \text { deep, } \\
\text { retained by terrace wall }\end{array}$ & 264719 & 1140 & 40 & $800-987$ \\
\hline 17 & 25 & a & $\begin{array}{l}\text { Layer underlying pebble strip 2011, at } \\
\text { the base of terrace wall } 2012\end{array}$ & 282086 & 1080 & 40 & $889-1021$ \\
\hline 18 & $15-52$ & 0 & SU 109, western section of TR15 & 264714 & 1010 & 40 & $966-1155$ \\
\hline 19 & & US 32 & $\begin{array}{l}\text { Charcoal and ceramic-rich dump layer } \\
\text { related } \\
\text { to structure buried under Wall } 3\end{array}$ & & & & $1000-1150$ \\
\hline 20 & 52 & DR 126 & On top of stones infilling drain 126 & 265269 & 970 & 40 & $1010-1159$ \\
\hline 21 & 15 & VIL $15-4$ & SU 109, eastern section of TR 15 & 264709 & 930 & 40 & $1023-1187$ \\
\hline 22 & 2 & US 32 & $\begin{array}{l}\text { Charcoal and ceramic-rich dump layer } \\
\text { related } \\
\text { to structure buried under wall } 3\end{array}$ & 264711 & 890 & 40 & $1035-1219$ \\
\hline 23 & 52 & DR 126 & Between the stones infilling drain 126 & & & & $1100-1450$ \\
\hline 24 & 52 & $D R 125$ & Between the stones infilling drain 125 & & & & $1100-1450$ \\
\hline 25 & 12 & VIL 1.1 & $\begin{array}{l}\text { In the soil retained by walls } \\
101-116 \text { (between } 0.5 \cup 1.10 \mathrm{~m} \text { deep), } \\
\text { over the coarse } \\
\text { gravel channel }\end{array}$ & 265270 & 680 & 40 & $1263-1394$ \\
\hline 26 & 1 & US 30 & $\begin{array}{l}\text { Destruction layer of a dwelling, } 49 \\
\text { pottery sherds }\end{array}$ & & & & $1275-1350$ \\
\hline 27 & 52 & DR 125 & $\begin{array}{l}\text { Below the base slab of drain } \\
125 \text {, in physical contact with the } \\
\text { slab }\end{array}$ & 264707 & 620 & 40 & $1288-1405$ \\
\hline 28 & 52 & DR 125 & Between the stones infilling drain 125 & 264710 & 600 & 40 & $1294-1411$ \\
\hline 29 & 3 & US 13 & $\begin{array}{l}\text { Occupation layer of the dwelling, } 152 \\
\text { sherds }\end{array}$ & & & & $1300-1500$ \\
\hline 30 & 15 east & COL 102-117 & $\begin{array}{l}\text { Between stones infilling the water } \\
\text { collector } \\
\text { 102, above MR Wall 116-Other } \\
\text { similar sherd in Drain } 117\end{array}$ & & & & $1300-1600$ \\
\hline
\end{tabular}

There were three main chronological phases in the village. The oldest features correspond to a rubbish dump (FIG. 3: e), which has been dated by pottery typology and radiocarbon dating to the 11 th-12th centuries (Beta-264711) (TABLE 1: date 22). Trenches opened over the buildings revealed multiple transformations in the village during the 13th-14th centuries. The village was then abandoned in the second half of the 14th century, at least in the northern sector, and no ceramics have been found that date 
after A.D. 1400. In the southern sector, but beyond the studied zone and therefore also our trial trenches, there is a group of better-preserved walls from dwellings (FIG. 3: f), which may be evidence of later construction. Some of these walls were partly reused as foundations for the northern wall of the Se.

\section{The fields according to the surface surveys}

The DGPS field survey found 340 archaeological features in the fields. There are four categories of features: those related to parcels (terrace walls and earthbanks, enclosure walls), circulation networks (ramps and paths), hydraulic networks (irrigation and drainage systems), and other features such as clearance cairns and undetermined forms (FIG. 3).

The $\mathrm{Ce}$ and Ee walls were repaired and changed several times in response to the progressive accretion of the soil from the large terraces above. These large terraces have relatively similar profiles with earthbanks 2-4 m high, and various construction techniques were used ranging from simple retaining earthbanks to dry-stone walls, some with a combination of both. These terraces were reached by a series of access ramps that may have been suitable for carts and were laid out in a wheel spoke shape (FIG. 3: g). Other terraces, with much more erosion and erased profiles, are also embedded in this set of terraces and seem as if they were swallowed up within the larger terraces (T1058 and T1039 for example). In addition to the access ramps to these large terraces, surveys also revealed a section of a north-south path (FIG. 3: h) near the alluvial fan, limited by two stone walls (W1113 and W1112).

Like the ramps of the large terraces, the main irrigation network is also consistent with the main lines of the current landscape. It takes water in from Clots Creek $150 \mathrm{~m}$ northeast of the area and divides into two branches east of the $\mathrm{Ne}$ wall One branch crosses under the Ne's eastern wall under a small bridge built into the wall (FIG. 3: i) to irrigate the terraces above. The other branch runs along the Ne's southern wall through a canal bordered with stone and irrigates terraces 1009 and the central meadow $(\mathrm{Ce})$. A second irrigation canal (FIG. 3: j), more recent, is built $100 \mathrm{~m}$ below and crosses the Ee wall. The drainage system is constituted by another network of ditches that, in contrast to the irrigation ditches, were built along the downslope limit of the terraces, just above the retaining walls that they protect from erosion.

We have seen that the southern and western walls of the Ce overlay the walls of some village houses and thus are later than the village. The $\mathrm{Ne}$ also revealed a complex history. On its eastern side, it probably overlaid the small terraces that are built up the slope there (FIG. 3: k). Later, however, this enclosure underwent a considerable leveling that corresponds to the creation of terrace T1123. This leveling left a ridge of earth against the eastern wall of the enclosure (FIG. 3: $\mathrm{m}$ ) and may explain the disappearance of the western wall of the enclosure. The leveling also covered a part of the north-south path. The path also underwent several changes. Its heterogeneous eastern border reveals at least three phases: an altered earth bank (T1114), which was rebuilt by a stone border wall (W1112), and was finally dismantled with a blasting drill. The earthbank T1114 turns southward and slants towards the east. It progressively disappears from the surface but constitutes the morphological element that determined the path of the southern wall of the Ne.

Maps and photos of these features provide some absolute chronological indicators. Almost all of the boundaries of the four enclosures and the large terraces correspond to the limits of parcels on the 1829 cadastral map and thus existed at that date. There are, however, three exceptions as follows. The construction of T1123 probably reworked the $\mathrm{Ne}$ between 1829 and the aerial photography of 1942 (where it appears). Secondly, the north wall of the Ne is not recorded on any cadastral map. Of course, it may have been in use very late without constituting a property boundary, but the reworking of the enclosure by T1123 suggests that it had already been abandoned when the first cadastral map was drawn in 1829. Finally, the north-south path segment appears in 1829 as a simple parcel boundary and has disappeared from the current cadastral map. A probable land rearrangement thus occurred after 1829. This may correspond to the dismantling of its stone border with a blasting drill, a tool that was used in the Cerdagne between 1750 and the beginning of the 20th century (Martzluff 2009).

\section{Stratigraphies in the terraced fields}

Forty-four trenches were opened on 6 ha of land for a total of $2264 \mathrm{sq} \mathrm{m}$. Eighteen of the trenches revealed no features, including trenches TR28 and TR33 that cut through embankments that were most probably natural. The 26 other trenches enabled us to study 52 archaeological features. Among them, 15 features had been observed during surface surveys (walls, embankments, canals) and 37 were totally buried and unobservable from the surface.

The geographical breakdown of these 52 features highlights the richness of two sectors: the periphery of the alluvial fan on the east, and the periphery of the moraine on the west, with its large terraces T1009, T1015, and T1050 (FIG. 4). Both of these sectors are characterized by the presence of drainage networks and by the preservation of several stratigraphic layers. However, on the granite slope where soils become thinner, preserved structures are very rare and have never been integrated into polyphase stratigraphies. 

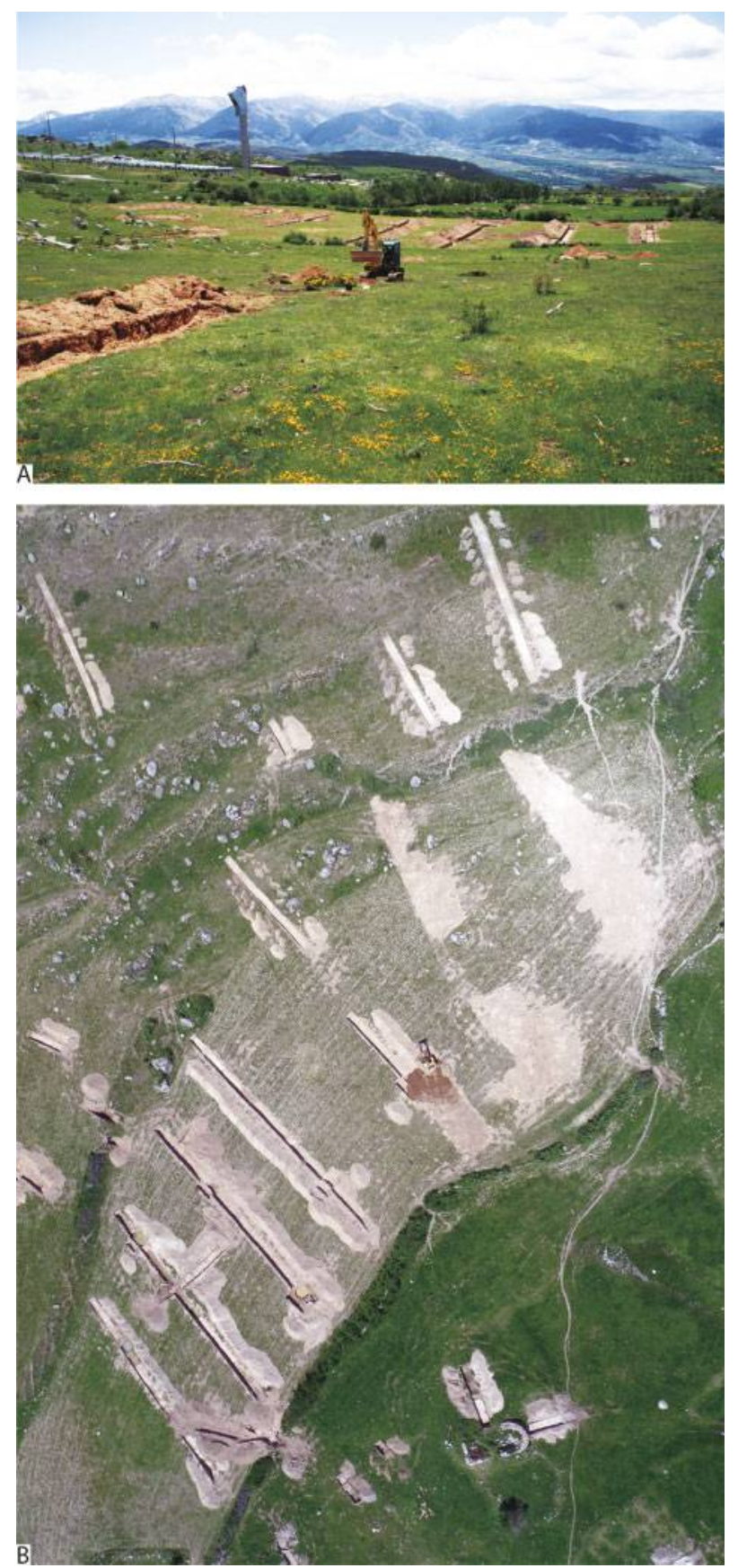

Figure 4 General view of the Vilalta evaluation. A) South facing view from terrace T1087; B) Aerial view by kite, directly over T1009.

WESTERN SECTOR: LARGE TERRACES BORDERING THE MORAINE

TR15, TR15bis and TR52 (FIG. 5A) sought to cut through the retaining walls of T1009 to evaluate the dynamics of infilling at this location, to evaluate the possible extension of the village above this wall, and to see what relationship might exist between this wall and the drainage network in TR 11 and TR12. Bedrock was not reached. The entire history shown by the stratigraphy was divided into three phases, corresponding to the two or three successive walls nested within each other and corresponding to several levels of drains (FIG. 5B).

In Phase 1 of T1009, the first wall (116) cuts through level 109 corresponding to a soil that was extant prior to the creation of the terrace. This level is made up of light brown, sandy clay sediment, conserved at around a dozen centimeters thick with dispersed charcoal fragments. This wall, excavated for 5 meters in TR15bis on the east runs parallel to the current terrace wall. The wall has a traditional retaining-wall structure, with large, regular shaped blocks on the outside face and a dense pile of pebbles for drainage on its inside face. This wall has retained an anthropized soil 108 containing dispersed charcoal pieces and pottery fragments. This soil was probably the earliest arable soil of the first terrace. It was drained by stone-filled drain DR 127, which cuts through the underlying layers 109 and 110 (FIG. 5D: 1). Two charcoal fragments found in level (109) were dated to the 11 th-12th centuries A.D. (FIG. 5B) (TABLE 1: dates 18 and 21).

In Phase 2 of T1009, the digging of DR 126, above drain DR 127 reflects the steady accretion of the terrace soils and the need to rebuild the infrastructure. Trench 52 shows that this drain was part of a complex network, since it was copied by a second parallel drain (DR 125), and both connect to the complex drainage network uncovered in TR 11 (FIG. 5A). This accretion of soil 108 probably also explains the rebuilding of the terrace wall, which resulted in the building of Wall 101 against the downstream face of Wall 116. One meter wide, this wall has large facing stones on both sides with a dense infilling of small stones. The excavation was too limited to be able to precisely determine if this was a freestanding terrace wall or a buttress wall for wall 116 . In the reconstruction, we opted for the first possibility (FIG. 5D: 2). Several artifacts and ecofacts were dated in this sequence. Two charcoal pieces obtained in DR 125 (FIG. 5C), one under a paving stone at the bottom of the drain and the other in the pebble filling, were dated to the 13 th-15th centuries (Beta264707, Beta-264710) (TABLE 1: dates 27 and 28). A pottery fragment found in the upper part of the filling of DR 125 was dated to the 12th-15th centuries (date 24). One charcoal fragment found on the surface of the filling of DR 126 was dated to 1010 1159 CAL A.D. (Beta-265269) (TABLE 1: date 20). Finally, a ceramic sherd from the interior of the pebble filling of DR 126 is dated to the 12 th-15th centuries (TABLE 1: date 23).

Phase 3 in T1009 corresponds to the construction of Wall 100, which is the current retaining wall of T1009. It is a trapezoidal section of a roughly built wall located $2 \mathrm{~m}$ downslope of Wall 166. It was partially built on level 112, which can probably be associated with the occupation/abandonment of the village. This wall, inside the terrace, corresponds to a new drainage system. This drainage system is composed of a bed of pebbles (layer 117) lying $0.3 \mathrm{~m}$ 


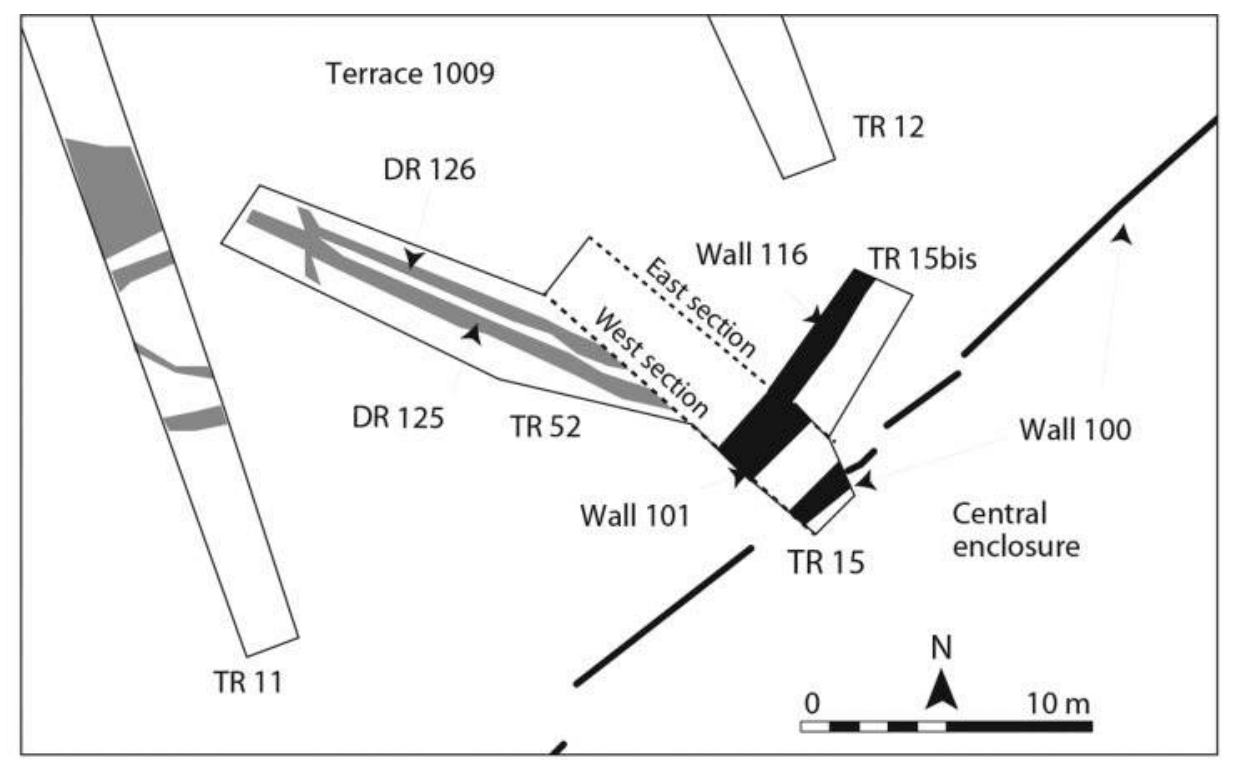

A

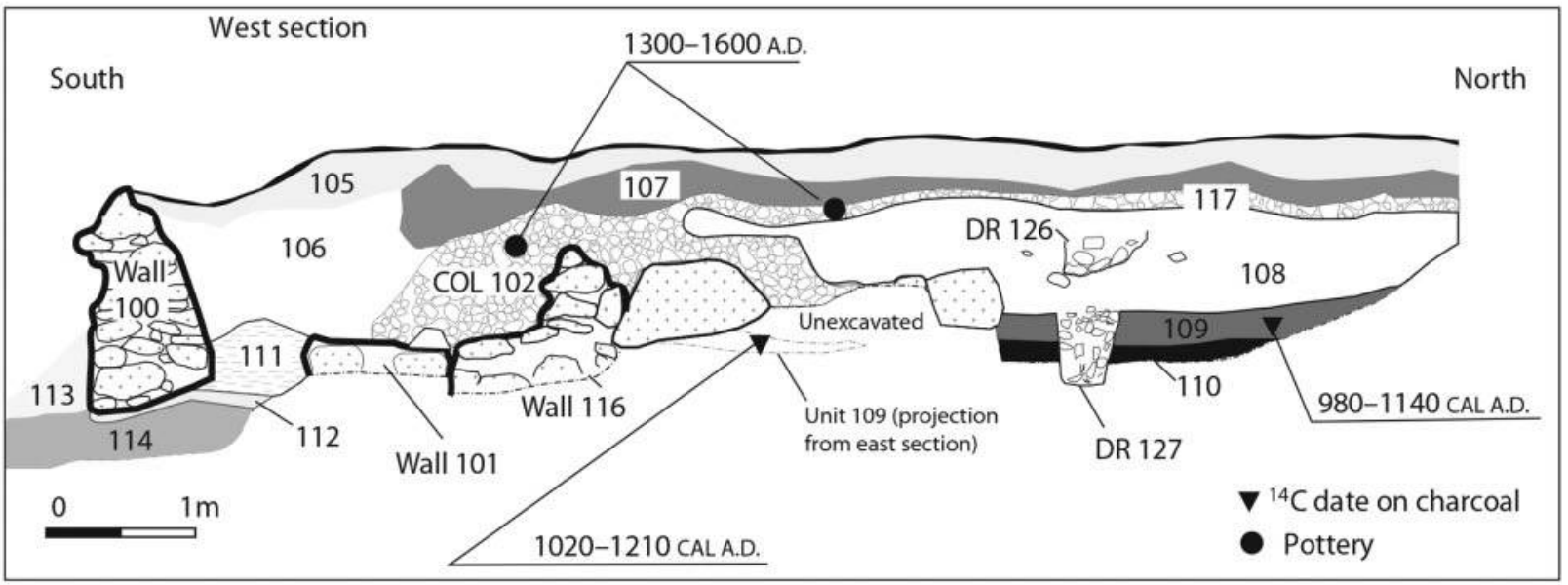

B
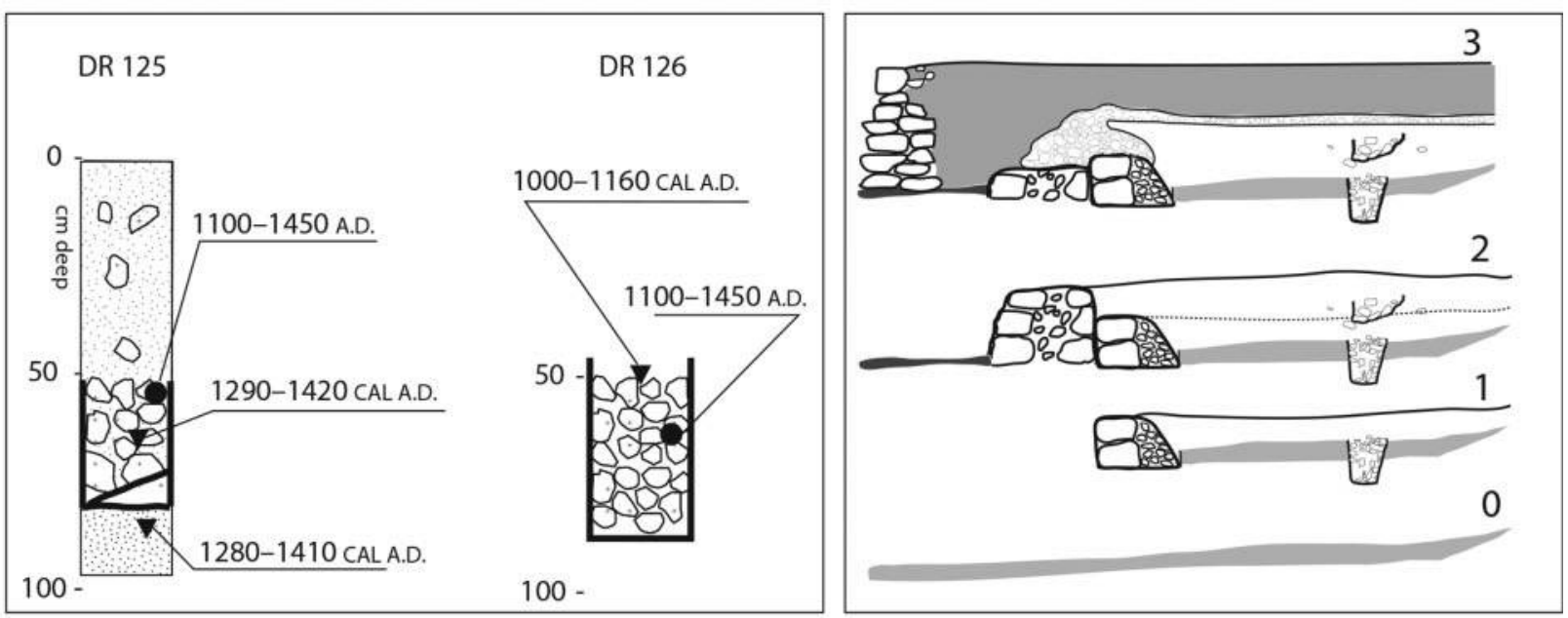

C

D

Figure 5 Map and section of TR 15, 15bis and 52. A) Locations of buried features; B) TR 15, west section: stratigraphy of walls, soils and drainage features ( $\mathrm{DR}=$ drains; $\mathrm{COL}=$ collector [water trap]); C) TR 52, stratigraphies of DR 125 and DR 126; D) TR 15, schematic reconstruction of the sequence.

below the surface that leads to a collector or water trap (COL 102) (FIG. 5B), which covers Walls 116 and 101. A layer of indurate, yellow, granular soil covers the entire section (US 107) and abuts a thin, yellow, indurate clay sediment (US 106) used to backfill the space between the wall and COL 102. 
At the top of the terrace, layer 105 corresponds to the arable topsoil of the current terrace. Two identical pottery fragments dated from 14 th -17 th centuries were found, one in COL 102 and the other in layer 107 (TABLE 1: date 30) (FIG. 5D: 3).

Other features in terrace T1009 (FIG. 6) were found between 40 and $50 \mathrm{~m}$ north of the retaining wall, where the sediment is less thick due to the rise of the granite bedrock. The first feature is a large charcoal lens $30 \mathrm{~cm}$ in diameter that indicates an older soil level $0.8 \mathrm{~m}$ deep. A charcoal fragment from that lens has been dated to 662-828 CAL A.D. (Beta-264715) (TABLE 1: date 13). A little further south of the second structure is a Wall (2001), which TR 14 (opened perpendicular to TR 12) enabled us to follow in a discontinuous manner for a minimum total length of $17 \mathrm{~m}$ (FIG. 6A). Located between 1.10 $\mathrm{m}$ and $1.30 \mathrm{~m}$ deep, in a level underlying the lens (122), the wall is made of stones measuring $20-30 \mathrm{~cm}$ in diameter. The wall measures $1.30 \mathrm{~m}$ wide and is preserved at about $30 \mathrm{~cm}$ high (FIG. 6). Covered by a sandy-silty homogeneous layer, then by a sandy-clay dark brown layer of nearly $70 \mathrm{~cm}$, this wall is built on a dark grey, sandy-silty layer particularly rich in charcoal fragments (level 1). One of these fragments, taken from under the base of the wall in contact with the stones, was dated to 1521-1383 CAL B.C. (Beta264716) (TABLE 1: date 5). Two handmade, tempered pottery fragments, without form or decoration and probably attributable without additional specifics to

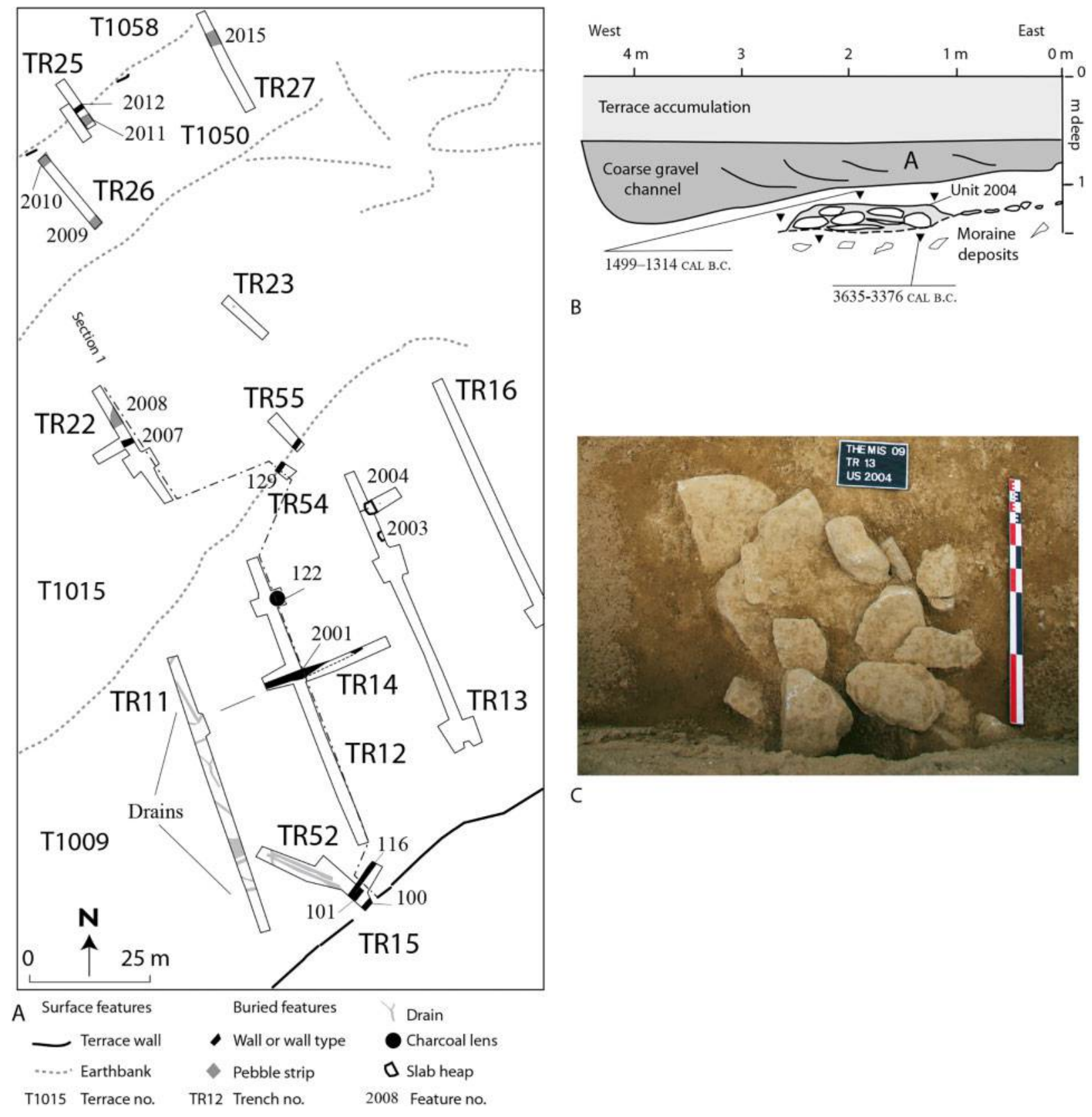

Figure 6 Buried features and layers in the lower terraces (T1009, T1015, T1050, T1058). A) Locations of features; B) Schematic west-east section of unit 2004, under the gravel channel in TR 13; C) Overhead photograph of the granite slabs (unit 2004, TR 13). 
the Bronze/Iron Age, were found on the surface of the wall (in TR 12) (FIG. 7D), and its continuation in TR 14.

At the same depth $(1.30 \mathrm{~m})$, two very similar small heaps of granite slabs, $1 \times 1.5 \mathrm{~m}$ in size, were found clustered together in TR 13 (units 2003 and 2004) (FIG. 6A). The slabs are each $30-60 \mathrm{~cm}$ in diameter. They are difficult to interpret, but the excavation of unit 2004 confirmed their anthropogenic origin because of the selected nature of the material and its very clear limits (FIG. 6C). They are buried by a thick channel of alluvial deposits composed of large gravel (FIG. 6B), and they lie on top of heterogeneous slope sediment from the moraine made up of granite blocks and small charcoal fragments. Charcoal taken from the level of unit 2004, under the channel, has been dated to 1499-1314 CAL B.C. (TABLE 1: date 6) and a charcoal fragment from the level below was dated to 3635-3376 CAL B.C. (TABLE 1: date 4).

In the middle of $\mathrm{T} 1015$, on the substrate at $1.10 \mathrm{~m}$ deep, TR 22 revealed the remains of a linear stone feature $0.80 \mathrm{~m}$ wide (unit 2007) (FIGS. 6A, 7E). This feature, perpendicular to the slope, may be a dismantled wall or a stone row to retain the soil (Roose and Sabir 2002). The stratigraphy shows several events (FIG. 7B). At the bottom, large blocks (level C) lie on red granite sand (level A). They were placed in a continuation with a line of pebbles (level B) that cut through and marked the ground level at the time of construction. This wall or stone row retained a level of coarse sand and silt (D), $0.15 \mathrm{~m}$ thick, whose southern end is marked by a dark-colored patch, richer in organic matter, probably preserved by the accumulation of rocks laying above it (level E). These rocks may correspond to another wall or a pile of stones. Two charcoal fragments, one taken from level $\mathrm{A}$ and the other from level D were dated to almost the same period: 1386-1123 CAL B.C. for the former (TABLE 1: date 8) and 1407-1191 CAL B.C. (Beta-264712) for the latter (TABLE 1: date 7).

Also in TR 22, unit 2008 is found some meters north of unit 2007 (FIG. 6A, 7E) but in a higher layer, only $0.4 \mathrm{~m}$ deep. It consists of a $2,0.5 \mathrm{~m}$ wide heap of pebbles that are each one decimeter in diameter, covered with a light brown, sandy-silty loose sediment. Interpreting this heap was made possible by identical deposits (units 2010, 2011 and 2015) found in TR 25, TR 26, and TR 27 (FIG. 6A). From one trench to another, they formed a continuous band, $1.5 \mathrm{~m}$ wide and from 0.3 to $0.5 \mathrm{~m}$ thick,

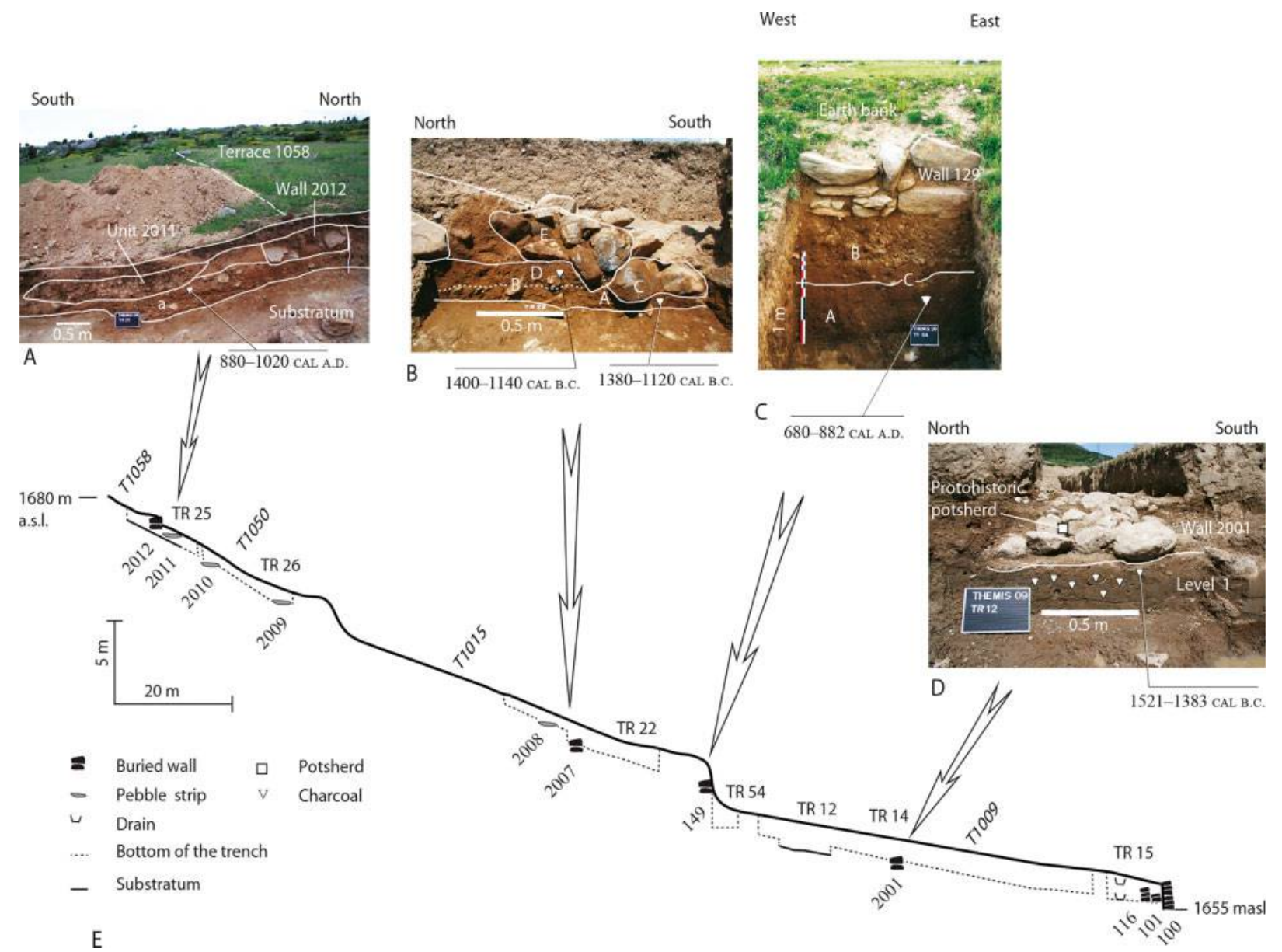

Figure 7 Locations and profiles of the main buried features and layers in the low terraces. A) TR 25, section of wall 2012 and unit 2011; B) TR 22, section of unit 2007; C) TR 54, front section; D) TR 12, section of wall 2001; E) Profile of the terrain along section 1 of figure 6 . 
which ran along the base of the Wall 2012 of T1058. This arrangement resembles the paths often found by Ballesteros Arias at the bottom of terrace banks that she has studied in Galicia (Spain) (Ballesteros Arias 2010: FIG. 6, 31-34). The fact that Wall 2012, very eroded, appears as if it has been swallowed up by T1050, and the finding of three parallel bands of pebbles on the slope (at the base of Wall 2012, unit 2009, and unit 2008) (FIGS. 6A, 7E), seems to indicate the existence of a buried system of small terraces. The stratigraphic profile of Wall 2012 (FIG. 7A) shows that it and the band of pebbles were built in the same sandy matrix, which is slightly carbonate and which includes a few rare fragments of charcoal. One of them was dated to 889-1021 CAL A.D. (Beta-282086) (TABLE 1: date 17).

Farther down the slope, TR 54 and TR 55 sought to obtain a better understanding of the slope of TR 1015, which is more than $2 \mathrm{~m}$ high with a few facing blocks in its lower part. The excavation of the front of TR 54 (FIG. 6A, 7E) showed that these blocks corresponded to a terrace wall, $0.8 \mathrm{~m}$ high (Wall 129), on top of which the earthbank reaches one meter high without any facing stones (FIG. 7C). Wall 129 itself was built on light brown, sandy silt loose sediment $0.6 \mathrm{~m}$ deep (level A), which covers an older soil $1 \mathrm{~m}$ deep, made of dark brown clay silt sediment, fairly rich in organic material and more compact (level B), containing little charcoal. Its surface is marked by a line of pebbles (level C). In the cross-section of the earthbank (TR 55), charcoal found in level B at the base of the wall was dated to 680-882 CAL A.D. (Beta-282087) (TABLE 1: date 14).

ON THE EDGE OF THE ALLUVIAL FAN

Sedimentary accumulations are very different in this sector, due to the proximity of the alluvial fan and a rather marked slope break between TR 45 and TR 47 (FIG. 8A, C). Up the slope from this break, TR 46 (FIG. 8B: profile 1) shows poor soil development. A brown soil horizon, $0.3 \mathrm{~m}$ thick, covers the level of alteration of the granite substrate. At the surface of this horizon there is a pit containing charcoal-rich sandy silt sediment (2023). One of the charcoal fragments has been dated to 3703-3526 CAL B.C. (TABLE 1: date 3 ). This ditch is immediately cut by two stonefilled drains, DR 2022 and DR 2024 (FIG. 8A).

Downslope from this slope break, the filling of TR 47 (FIG. 8A) reaches $2 \mathrm{~m}$ deep (FIG. 8B: profile 3). On the bottom, above the coarse sand from the granite alteration (level 1), the stratigraphy shows grey oxidized sand containing some charcoal fragments and some granite blocks (level 2), then a $0.65 \mathrm{~m}$ thick coarse sand deposit containing some silt and clay, which also contains charcoal and some highly weathered granite blocks (level 3). At the top of the stratigraphy, the small stream deposited $0.7 \mathrm{~m}$ of medium sand (levels 4, 5, 6). A charcoal fragment found in level 2 has been dated to $3771-3640 \mathrm{CAL}$ B.C. (BETA-264720) (TABLE 1: date 2).

Trench 45 (FIG. 8A) was placed at the slope break so as to cut through different features from north to south: the earthbank 1114, which, as we have seen, may have had a role in the morphogenesis of the field pattern in this area; the southern wall of the $\mathrm{Ne}$; and the stone-lined canal that runs along that wall. The sedimentary sequence is $1.10 \mathrm{~m}$ thick (FIG. 8B: profile 2) and shows, on top of the coarse sand layer (level 1), a layer of grey sand, rich in charcoal fragments that are often a centimeter in diameter, and which also yielded five handmade potsherds (level 2, unit 2005). At the southern part of the trench, this level is intersected by a drain (DR 2021) (FIG. 8A). In the north, this level is covered by $10 \mathrm{~cm}$ of sandy loam (FIG. 8B: profile 2, level 3), and then, between 0.75 and $0.5 \mathrm{~m}$ deep, covered by granite blocks that form the built structure of embankment 1114 (level 4, wall 2020). The stratigraphy ends with a $0.5 \mathrm{~m}$ sandy level (levels 5 and 6), on top of which are the structural elements of the current landscape, i.e., the $\mathrm{Ne}$ wall and the canal, the bases of which are $0.20 \mathrm{~m}$ deep.

Trench 42 (FIG. 8A) was designed to intersect the north-south path to observe its structure (FIG. 8D). As with the $\mathrm{Ne}$, its stone borders are very superficial. The stratigraphy confirms the presence of the path and reveals that there were at least two layers of successive use marked by the presence of small channels corresponding to ancient wheel ruts and lateral ditches. The most recent of the two levels (level E), contemporary with the stone borders, was built above an earlier level (level B), probably contemporary with embankment 1114 . Level B rests on a sandysilty level (C), laid on top of a very compact interface $\left(C^{\prime}\right)$, the entire ensemble being interstratified with a much earlier, lateral channel nearly $2 \mathrm{~m}$ wide (J). On the surface of C', some charcoal fragments were recovered, one of which was dated to $426-600 \mathrm{CAL}$ A.D. (beta-264708) (TABLE 1: date 11), and a ceramic fragment was found corresponding to the edge of a cup attributed to the Bronze Age/Iron Age transition (1000-700 CAL B.C.) (TABLE 1: date 9).

Downslope in the same sector, three other trenches yielded traces of planned use. TR 49 was dug on the edge of a small terrace dominating an enclosure (FIG. 8A: structures 1148 and 1149). This trench confirmed the existence of a wall at the end of the terrace, which was bordered on the south by a ditch, carved in the granitic weathered bedrock, reaching $1.3 \mathrm{~m}$ in depth (FIG. 8A: Wall 2025 and ditch 2026). The rapid rise of water in the trench precluded 


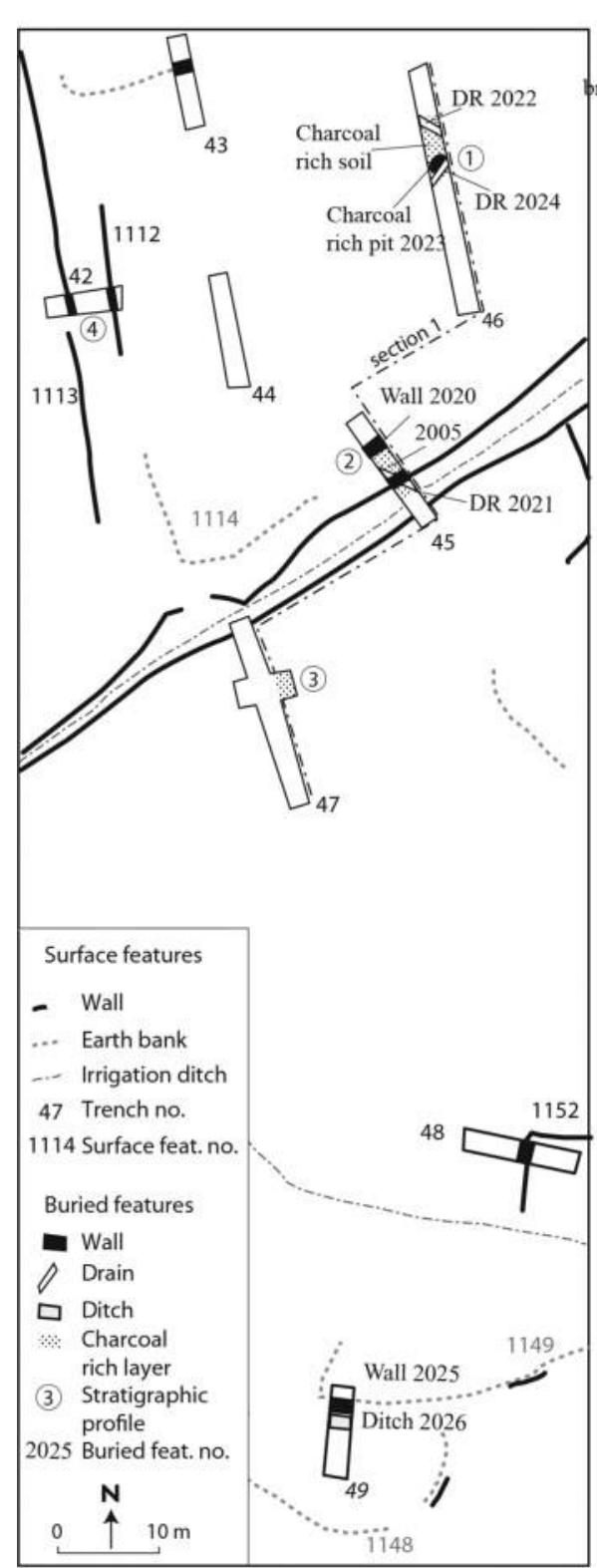

A

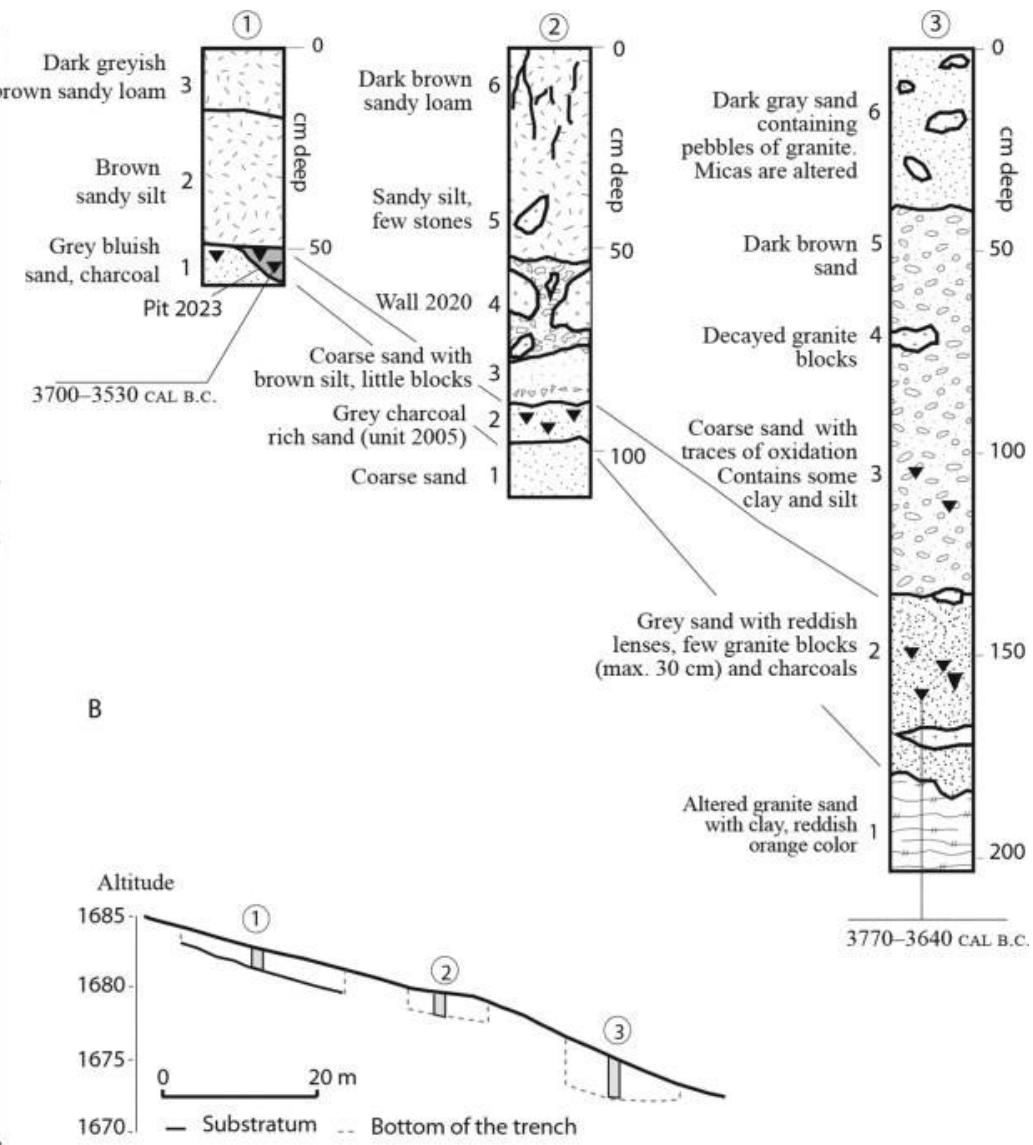

C

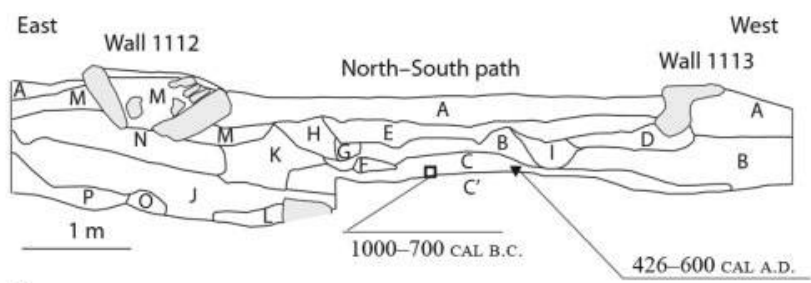

D

Figure 8 Locations and profiles of the main buried features and layers on the alluvial fan. A) Plan of the area; B) Sedimentary profiles of TR 46, TR 45 and TR 47, highlighting the correspondence between the levels rich in carbon and their dates; C) Three profiles on the slope; D) South section of TR 42 (profile 4).

more precise examination, but we were able to collect a few fragments of pottery and charcoal in the ditch's infilling. One of the charcoal fragments was dated to 582-694 CAL A.D. (beta-264717) (TABLE 1: date 12) and the ceramics are attributed to Roman Antiquity (100-400 CAL A.D.) (TABLE 1: date 10).

Finally, $130 \mathrm{~m}$ south of TR 49 on the other side of the stream, a partial rescue excavation was conducted in 2010 on the edges of a large earth mound that had been created during construction of the power plant. TR 8bis (FIG. 3) revealed a highly anthropogenic sediment, rich in charcoal, associated with a small hearth and a line of blocks that may correspond to a built structure. The feature has been interpreted as remains of settlement. A charcoal fragment from the hearth has been dated to 778-980 CAL A.D.
(Beta-287382) (TABLE 1: date 15), in accord with the ceramic material.

The highest altitude trenches on the site revealed three structures - two buried terrace walls in TR 37 and a charcoal lens in TR 34 (FIG. 3) - that were found in very thin soil. One charcoal fragment, from the TR 34 charcoal lens, was dated to 4721-4491 CAL B.C. (Beta265272) (TABLE 1: date 1). Another piece of charcoal from the base of the brown soil that is retained by wall 2029 (TR 37) and is rich in organic material, was dated to 800-987 CAL A.D. (TABLE 1: date 16).

\section{Discussion}

\section{Value and significance of absolute dates}

More than on-site excavations, excavations of agricultural land raise the question of the movement of 
dated artifacts or ecofacts in the soil and their relationship with anthropic features. In off-site excavations, and in particular in the case of terraces where the fill is constructed, we are always faced with intermixing of soil and the study of features must take this into account (Boissinot 2000: 38). Moreover, several recent studies on dating agrarian land transformations, and in particular terraces, have shown that multiplying the dates and contextualizing them within archaeological and sedimentary sequences enable the dates to be used profitably for archaeological analysis (see Schwartz et al. 2003; Kemp et al. 2006; Bal 2006; Bal et al. 2010; Borejsza et al. 2008; Frederick and Krahtopoulou 2008; Bevan et al. 2013; Davidovich et al. 2012).

The 30 dates collected at the Vilalta site range from the 5 th millennium B.C. to the 16 th century A.D., although with unequal coverage (TABLE 1) (FIG. 9A). Leaving aside the five dates from dwellings (TABLE 1: dates 15, 19, 22, 26 and 29) and two dates from the granite slope, which is devoid of developed soils and stratigraphy, 23 dates remain from artifacts or ecofacts from locations that are technically outside village habitation but do provide stratigraphies (located in the accumulations of the lower terraces and on the alluvial fan).

Overall, on the scale of the entire site, the first observation about these 23 dates is that their distribution shows no major chronostratigraphic inversion: the Medieval charcoal fragments are systematically located in layers above those that have yielded Bronze Age and Neolithic charcoals. Moreover, these latter charcoals are consistently clustered together in time and space. The only exception is the north-south path (TR 42). The presence in the same level of a piece of charcoal and a pottery fragment separated by 1500 years can be explained by the great disturbances resulting from the circulation of water in channels on the path.

On the smaller scale of a single trench, TR 15, the sequence of Medieval and Early Modern artifacts and charcoal dated there is also consistent with the stratigraphy. There is only one exception: the date of the highest point of DR 126 (1010-1159 CAL. A.D.) (Beta-265269) (TABLE. 1: date 20) (FIG. 5C), whose inversion can be explained by the filling in of the drain with the sediment from the bottom of the drain. It seems that neither the colluvium, nor the anthropogenic reworking have caused important enough stratigraphic disturbances for the dated charcoal and artifacts to be found far removed in time from their original contexts of production in a statistically significant way. The progressive nature of sediment accumulation observed in T1009 partly explains this general trait.

On the scale of archaeological facts, the dates obtained can be used profitably provided they are

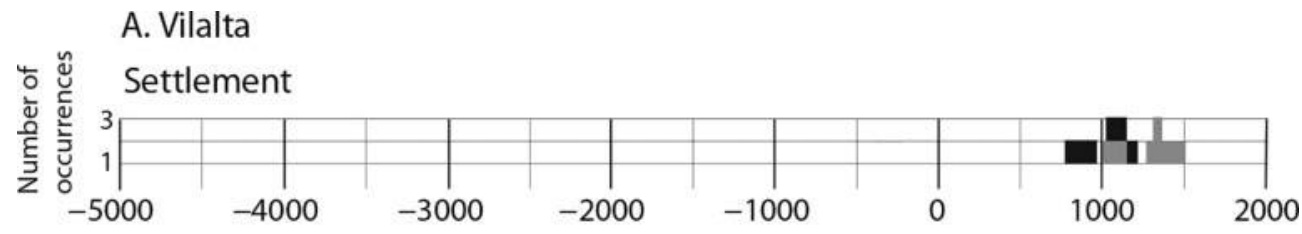

Fields

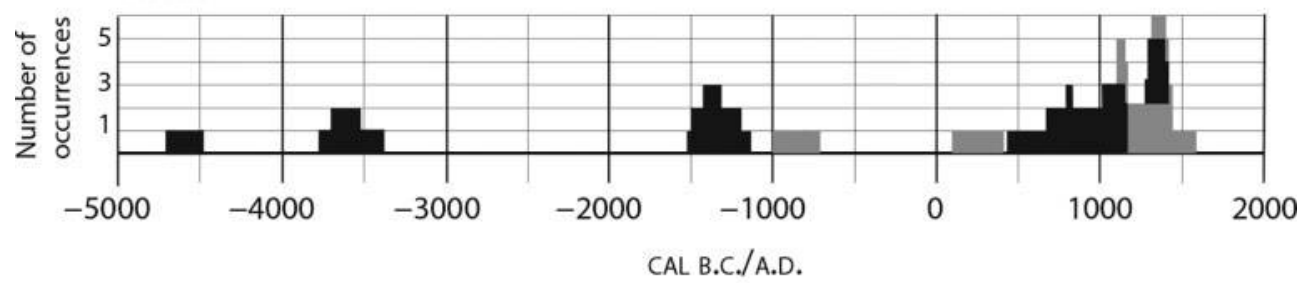

B. Enveig summer grazing sites

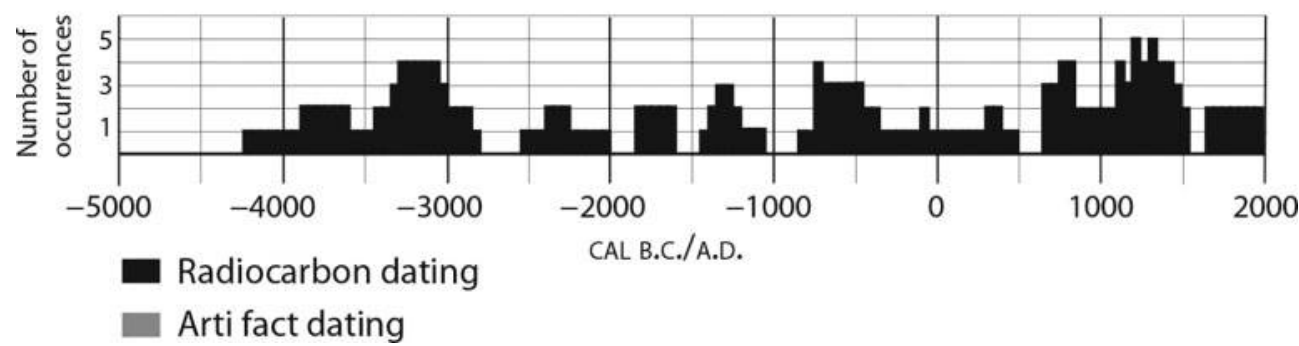

Figure 9 Cumulative histogram of radiocarbon and artifact dates at Vilalta. A) Time ranges for the settlement (5 dates) and fields (23 dates). The vertical axis represents the number of occurrences that the time interval is documented in the series of datings; B) Comparison with the radiocarbon dates from Enveig Mountain (south Carlit face). This histogram shows the radiocarbon dates from the excavation of 18 pastoral sites. 
interpreted with care. In isolation, these dates are only significant if they are from charcoal lenses or soils rich in undisturbed charcoal. The other dates, if they are in stratigraphic layers, only provide a terminus post quem for features. Thus, whether the artifacts or ecofacts collected can be used to date the features they were found next to must be discussed on a case by case basis.

\section{Suggested dating of features and reconstruction of the Dynamics of Agricultural Land}

The dates collected in TABLE 1 (FIG. 9A) highlight continuum and hiatus, both spatial and temporal. From the Neolithic to the beginning of the Middle Ages, the predominant fact is the strong concentration of dates in two relatively limited periods, the Middle Neolithic (ca. 3600 CAL B.C.) and around the Middle/Late Bronze Age (ca. 1350 CAL B.C.). Between these two periods, the gaps are immense: two millennia between the Middle Neolithic and the Bronze Age and nearly a millennium before Roman Antiquity, which itself is only weakly documented on this site. Despite the bias of this table, the distribution of dates, based on samples that were systematically selected for their relationship with anthropic structures, appears too singular to be merely by chance. Although this picture certainly does not reflect the entire use of the area, which must be documented by other local, paleoenvironmental data, it seems, however, that these dates do indicate certain key moments of land development. It is this hypothesis that we examine first, by analyzing the relationship between dates, sedimentary processes, and archaeological features for these early periods, which we then place into the context of the entire region. Then, for the Middle Ages and Early Modern era, we suggest multiple phases for land development and examine the questions that this phasing raises in relation to settlement dynamics.

\section{NEOLITHIC}

Leaving aside the date of 4721-4491 CAL B.C. (Beta265272) (TABLE 1: date 1), without any context, two of the three Neolithic dates are chronologically very close (Beta-264720, Beta-264718) (TABLE 1: dates 2 and 3 ) and come from a rich wood charcoal layer found at the edge of the alluvial fan in the coarse sand from the granite bedrock alteration at the base of TR 45, TR 46 and TR 47. The similarity of sedimentary contexts and dates means this can be understood as the same level. The presence of a pit and the discovery of handmade potsherds, without decoration or shape but attributable to recent prehistory or protohistory (TR 47 and TR 45), argue for considering this layer as evidence of human activity or occupation rather than a natural fire event, considering the rarity of ceramics in the overall excavation. In the Cerdagne region, and particularly on Enveig Mountain on the same Carlit massif (FIG. 9B), this period is fairly well documented. Consistent with other areas in the Pyrenees (Galop 2006), and in particular with recent studies in Andorra and in the upper valley of Pallars (Orengo et al. 2014; Gassiot et al. 2012), the data for the region is evidence for an increase in anthropic impact at all altitudes, including the high mountains (presence of sites, growth in pollen and pastoral indicators) (see Galop 1998: 78; Rendu 2003: 522-526). Even in the granite boulders, $2 \mathrm{~km}$ west of the Angoustrine moraine, four rockshelters contained Chassean ceramics, characteristic of this period (Vaquer 1976). All of this data supports the hypothesis of human occupation or activity at Vilalta, although this cannot yet be characterized precisely given the limited nature of the rescue excavation.

\section{BRONZE AGE}

Several stratigraphic arguments enable us to attribute the construction of Wall 2001 and the slab heaps 2003 and 2004 to a pre-Medieval period. The first is the sealing of Wall 2001 by the level of soil comprising lens 122, dated to 622-828 CAL A.D. (Beta264715) (TABLE 1: date 13). The second resides in the sealing of feature 2004 by a natural thick channel of coarse gravel that was deposited prior to the construction of the Medieval and Early Modern terraces (FIG. 6B). In fact, structure 2004 is in an interface position, as it was built on deposits from the lateral moraine and under the earliest alluvial deposits. In addition, the depth of Wall 2001 and structures 2003 and 2004 is identical (about 1.10-1.30 m below the surface) and they are very close spatially (less than $20 \mathrm{~m}$ between the east end of wall 2001 and the heaps of flat stones).

Given this spatial and stratigraphic proximity, the radiocarbon dates contribute weighty evidence for situating these features in the Late Bronze Age-or, if we presume a generalized old wood effect, within a large timespan up to the beginning of the Iron Age. Wall 2001 was built on soil whose richness in charcoal (averaging a centimeter in diameter) can be explained by a fire or by slash-and-burn clearing before building the wall. One of the pieces of charcoal, found in contact with the wall, has a date of 1521-1383 CAL B.C. (Beta-264716) (TABLE 1: date 5), very close to the date of feature 2004 (1499-1314 CAL B.C.) (Beta-265271) (TABle 1: date 6). Finally, these dates are also chronologically close to those obtained from two charcoal fragments found under and abutting feature 2007, observed in TR 22, about $50 \mathrm{~m}$ to the north (14th-12th centuries CAL B.C.) (Beta-264712, Beta-264713) (TABle 1: dates 7 and 8 ). One of these fragments was found under 
the wall and the other was from sediment retained by the base of the wall and then covered over by a pile of stones.

The absence of ceramics near these structures does not argue for habitation, but rather for agrarian structures (such as a boundary or fencing wall for wall 2001, a terrace wall, or a stone row or stone heap for feature 2007). The hypothesis that we favor, at the current state of the data, is to consider all of these features as evidence of the organizing of the agricultural land, and perhaps the development of field boundaries between the end of the Middle Bronze Age and the beginning of the Iron Age.

In the Cerdagne, such an occurrence would not be unique. If this hypothesis is confirmed, it would contribute to a growing body of evidence that shows remarkable agro-pastoral organization on the slopes of the Cerdagne at this time. On the Enveig slope, in the subalpine zone, large semi-permanent settlements, such as farms, have been excavated and dated to the 18th-11th centuries CAL B.C. (Rendu et al. 2012). These dwellings are strongly associated with wood clearing (Galop et al. 2007: 110). Also at Enveig, but in the mountain zone between 1600 1900 masl, a series of excavations revealed the existence of a first generation of terraces that have been dated several times to the 3rd-2nd millennia CAL B.C. and buried under the terrace systems that are visible on the surface (Bal 2006; Harfouche 2005; Bal et al. 2010). Furthermore, an analysis of the plant remains from the Llo oppidum (1600 masl) revealed an agrarian system that was based, in the 14th-13th centuries CAL B.C., on cultivation of grains and pulses (peas, barley, wheat). The weed assemblage reveals that there were permanent fields in a cleared area, cultivated intensively (Ruas et al. 2009).

IRON AGE-ROMAN ANTIQUITY

The series of dates at Vilalta then presents a long hiatus of more than a millennium, from the late second millennium CAL B.C. to the early 1st millennium CAL A.D (FIG. 9A). The only chronological indicator for this period is a ceramic sherd in secondary position in TR 42 , dated to the range of 1000-700 CAL B.C. (TABLE 1: date 9). This absence of data is not necessarily the result of an interruption in the site's use and cannot be interpreted definitively at this stage of research. We do know, however, that numerous sites excavated in the Cerdagne basin, including at altitudes similar to that at Vilalta (FIG. 1), show that some agglomerations, hamlets, or dispersed buildings at this time period are associated with grain cultivation (Campmajo 1983, 1991; Bousquet et al. 2014; Martzluff 1998; Kotarba et al. 2006).

The next dates that follow chronologically are from ditch 2026 observed in TR 49 (on the alluvial fan), associated with a buried wall whose surface relief corresponds to the shape of a small terrace. The dating of one of the charcoal fragments from the ditch infilling (582-694 CAL A.D.) (Beta-264717) (TABLE 1: date 12) has no evidentiary value. Yet, this date is associated with well-dated ceramics (100-400 CAL A.D.) (TABLE 1: date 10): a fragment of an amphora (1st-4th centuries A.D.) and a fragment of southern Gaul Samian pottery, attributable to the 1st-2nd centuries A.D. (determination by J. Kotarba). The scarcity of archaeological ceramics over the entire zone and the absence of abrasion on the pottery sherds leads us to postulate that the ditch and perhaps the adjacent T1149 and enclosure 1148 may date to Roman Antiquity. However, in the absence of further excavations the question remains open.

\section{THE MIDDLE AGES AND THE EARLY MODERN PERIOD}

The 5th century A.D. marks the beginning of a period of overlapping dates (FIG. 9 A). The fact that six of the 22 radiocarbon dates from the fields are between the beginning of the 7 th and the beginning of the 11th century CAL A.D. (Beta-264717, Beta-264715, Beta282087, Beta-287382, Beta-264719, 282086) (TABLE 1: dates 12 to 17$)$ roughly argues for an increase in human activity during this period, before the establishment of the village. These six dates might also result from later activity in the space, creating a generalized "old wood effect." Yet, the presence of a probable habitation in TR 8bis dated to 778-980 CAL A.D. (BETA-287382) (TABLE 1: date 15) suggests that dispersed settlement prior to the village may have been the reason for the first terracing of the slope, similar to what has been observed in Galicia (Quiros Castillo 2009). The terminus post quem of walls T1015 and T1058 (Beta-264715, Beta-282087) (TABLE 1: dates 13 and 14) does not contradict this hypothesis, but more definitive evidence is needed before advancing firm conclusions.

As expected, the main phase of field creation and soil accretion is medieval and contemporary with the existence of the village, as shown by the cumulative table of dates (FIG. 9A) and the very coherent chronostratigraphy in TR 15 (FIG. 5). The three phrases of the sequence can be dated fairly precisely. The terminus post quem for the first phase can hardly be before the two dates of level 109 (Beta264714, Beta-264709) (TABLE 1: dates 18 and 21), thus dated to 966 CAL A.D. That of the second phase from, based on date 27 (TABLE 1) (charcoal under a paving stone at the base of DR 125) is dated to 1288 CAL A.D. This latter date is coherent with the ensemble of dates obtained on artifacts from the fill (TABLE 1: dates 23, 24, 28), which give a range of 1100 to $1450 \mathrm{CAL}$ A.D. We have seen 
that the date 20 of 1010-1159 CAL A.D. (Beta-265269) may be explained by a backfilling of the drain using sediment from the bottom of the drain. Finally, the last phase of development observed (phase 3) is most likely after the abandonment of the village. Two elements support this argument as follows. The terminus post quem of wall 100 and its drainage system is given by three lead-glazed pottery fragments found in levels 117 and 102, which can be attributed to the 14th-16th centuries (TABLE 1) and the fact that wall 100, in the western part of the Ce clearly ends up covering over the houses of the village.

Generally speaking, the trenches on the alluvial fan bring to light a fairly similar time sequence, despite very thin sedimentation. The south wall of the $\mathrm{Ne}$ and its bordering canal, both of them very superficial, obliterate previous features including the 1114 earthbank, the north-south path in its earliest state, and the drainage system found over almost $2000 \mathrm{sq}$ m (TR 45, TR 41 and TR 46) (FIG. 8A). The similarity with the terrace T1009 sequence thus encourages us to broadly connect the first phase with the Medieval period and the second phase in the $\mathrm{Ce}$ and $\mathrm{Ne}$ to the Early Modern period.

Moreover, various elements enable us to suggest a history focused around two principal moments for the system of large terraces of the moraine slope as well. As we have seen, several pieces of evidence suggest that the large terraces with earthbanks covered over an earlier organization of small terraces made with stone retaining walls: the composite structure of the edge of T1015 (earthbank on top of a stone retaining wall); T1058 and its pebble pathway being swallowed up by T1050; and the discovery of several identical and parallel paths within the large terraces T1015 and T1050, arguing for the existence of a system of small stepped terraces. Following the terminus post quem of different walls (Beta-282087, Beta-282086) (TABLE 1: dates 14 and 1), this first system did not exist before the 9th-11th centuries A.D. Everything leads us to believe that it was contemporary with the village and was rebuilt after the village was abandoned. It is difficult to say whether this rebuilding of the slope happened at one moment in time or over a long period. The centralization and the uniformity of the access ramps that lead to the large terraces argues for the first theory and for a sort of planned rebuilding. The later creation of T1123, which, contrary to the other large terraces, was after the Napoleonic cadaster, argues in favor of a process that was spread out over time.

In the end, the issue raised for this last millennium of history is that of the comparative resilience of the agrarian landscape and habitat. The village of Vilalta, an ephemeral and fragile center of population if studied alone, would lead us to accept all of the clichés about the abandonment of medieval villages created on the extreme margins of arable lands during periods of growth, and immediately abandoned in times of crisis, leaving behind an abandoned landscape that has not changed since. Enlarging the archaeological evaluation to include agricultural infrastructures changes the picture. On the contrary, evidence from fields shows construction over the long term and frequent reworking. The probable habitation discovered in TR 8bis, as well as a charter from A.D. 1035, which mentions a certain number of inhabited places in this sector that had disappeared by the 12th century, supports the hypothesis that the village succeeded a pre-existing dispersed settlement. In fact, such a hypothesis follows a common pattern well-demonstrated in neighboring examples on the Roussillon Plain (Passarrius et al. 2008). Thus, in the case of Vilalta, it appears that we are seeing a more traditional transformation of agrarian lands and not a process of colonization of mountain zones.

The climate change in the Little Ice Age and the great demographic depression at the end of the Middle Ages may be sufficient explanations for the extinction of a village at 1650 masl at the turning point of the 14th and 15th centuries. However, the fact that there was a phase of intensive exploitation of the agricultural land, requiring expensive investment, which followed the abandonment of the village and persisted throughout the Little Ice Age, reveals a more complex adaptation of agrarian structures to socio-environmental changes. The establishment of a new drainage system, in the face of an increase in precipitation that has been well proven for the eastern Pyrenees (Carozza et al. 2011) is perhaps one aspect of this adaptation. Yet, this must be combined with other kinds of evidence such as the processes revealed in written documents. From the 14th-16th centuries, this documentation describes the creation of enclosed meadows that resulted from both demographic contraction and the progressive appropriation of collective slopelands by the mas, or individual farms (Bille 2004; Conesa 2012). This process, which became more pronounced in the 17 th century, went hand in hand with the restriction of the usage rights of peasants on common lands, the intensification of the land market, and capitalistic investment in cattle-raising. This shift towards a speculative economy, which began in the 15 th century, intensified with the increase in beef consumption in Catalonian towns (in particular Barcelona) in the 18th century. The extension of irrigation networks and enclosures (bocage) accompanied this conversion of arable land into meadows. The relations with urban markets, the importance of capital, and the risks explain the bourgeoisie's investment in these large mountain sites until the 19th century. 


\section{Conclusions}

The first result of this study resides in the pertinence and relevance of combining methods in this way to investigate agricultural land in the mountains. Rescue archaeology methods, which are rarely applied to mountain zones, combined with a large series of radiocarbon dates have enabled us to reconstruct the agrarian landscape, its developments, its inheritance from the past, and its adaptations over a very long period. In addition, this study highlights the usefulness of combining sedimentary archaeology with surface surveys and their contribution to an Early Modern and contemporary archaeology of the landscape, which is essential for reconstructing a history of spatial dynamics over the long term.

The chronology that we have discovered breaks quite radically with pre-conceived hypotheses about this landscape. Evidence on the development of the agrarian landscape during the Bronze Age remains partial due to the fragmentary nature of rescue trenches, but there is enough evidence to form more than a simple hypothesis. Put with other data acquired on a regional scale, the evidence shows that in the 2nd millennium CAL B.C., there was specific management of various forms of agrosylvo-pastoral exploitation at different altitudes suggesting the existence of territorial organization. Thus, the data invite us to develop additional research on intermediate altitudes, which have rarely been the object of in-depth studies.

The establishment of the medieval village obviously remains a key moment in the slope's exploitation, but it is not the only significant moment. By demonstrating the importance of earlier and later slope transformations, this study encourages putting an end to the idea, too often accepted for mountainous zones, of the immobility of the medieval landscape after the abandonment of villages. Moreover, the correlation with written sources enables a more detailed analysis of the weight of socioeconomic and environmental factors in the processes of transformation.

By changing the focal point of observation and by fully integrating agricultural lands into this study, this archaeological assessment also highlights the diversity of successive spatial systems. Although the changes observed here need to be examined in further detail with future excavations, they reveal the astonishing malleability and adaptability of these mountain spaces, as well as their deep interaction with the socioeconomic changes of the surrounding areas. Finally, they also highlight the considerable archaeological potential of intermediate altitude terraced fields.

\section{Acknowledgments}

This archaeological evaluation was organized by the Archaeology Center of the Department of PyrénéesOrientales headed by Olivier Passarrius. The excavation's specifications and objectives were defined by the Archaeology Department of the LanguedocRoussillon region (French Ministry of Culture). We would also like to thank the French National Center for Scientific Research (CNRS), the University of Toulouse and the Spanish National Research Council (SCIC) for their support and Cynthia J. Johnson for her assistance in translating and editing this article. We would also like to thank the anonymous reviewers for their constructive comments.

Charles F. W. Higham (Doctor of Science 1991, University of Cambridge) is a Research Professor in the Department of Anthropology and Archaeology, University of Otago. He co-directed the excavations of Ban Na Di, Khok Phanom Di, Non Muang Kao, Nong Nor, Ban Lum Khao, Non Muang Kao, Noen U-Loke, Ban Non Wat, and Non Ban Jak. His research is centered on the prehistoric origins of early states in Southeast Asia.

Christopher H. Roosevelt (Ph.D. 2003, Cornell University) is an Associate Professor at Boston University and Director of the Kaymakçı Archaeological Project. His research interests include archaeological and spatial technologies, especially as implemented in the archaeology of Bronze and Iron Age Anatolia and the eastern Mediterranean.

Peter Cobb (M.S. 2008, University of North Carolina at Chapel Hill) is a Ph.D. candidate in the Art and Archaeology of the Mediterranean World program at the University of Pennsylvania. His research interests include the ceramics of western Anatolia during the second millennium B.C.E.

Çiler Çilingiroğlu (Ph.D. 2009, University of Tübingen) is an Associate Professor in the Department of Protohistory and Near Eastern Archaeology at Ege University in Izmir, Turkey. She has published widely on the neolithization of western Turkey, maritime connectivity in the Aegean, various aspects of Neolithic and Chalcolithic material culture, and archaeological practice in Turkey.

Muriel Llubes (Ph.D. 1998, University Paul Sabatier, Toulouse, France) is an Associate Professor in Earth Sciences. Her principal research interest is in applied geophysics for archaeological purposes. She has worked on several collaborations with specialists of mining activities and numerous research programs in France, Spain, Italy, Tunisia, Romania, Croatia, Honduras.

Pauline Illes (M.A. University of Perpignan, France) provided technical support to the Vilalta rescue evaluation as part of the Archaeological Department of the Pyrénées-Orientales. Her master's research focused on river 
crossings at the end of the Middle Ages in Roussillon, France.

Pierre Campmajo (Ph.D. 2008, Ecole des Hautes Etudes en Sciences Sociales, Toulouse) is an Associate Researcher at the Traces Research Group. As a specialist in the Pyrenean cultures of the Bronze and Iron Ages, he has directed the excavations at the oppidum of Llo from 1970-1987 and since 2009. He is also a researcher of post-glacial rock engravings. He has coordinated the collective research project on the Bronze-Iron Age transition in the Eastern Pyrenees since 2009.

Clara Jodry (M.A. 2011, University of Pierre and Marie Curie, Paris VI) is currently a Ph.D. student at the Sciences of the Universe observatory at Nantes University. Her main research concerns the geophysics of subsurfaces. She conducted the electrical resistance survey of the Vilalta village under the supervision of Muriel Llubes. Her Ph.D. concerns the monitoring of protective structures against flooding by geoelectric methods.

Denis Crabol is an archaeologist and President of the organization Historical and Archaeological Research Group of Cerdagne (GRAHC). He supported every stage of the Vilalta excavation, from the surface surveys through the writing of the final paper.

Elisabeth Bille (Ph.D. 2004, University of Toulouse) is an Associated Researcher at the Framespa Research Group in Toulouse. Her research focuses on the social and political organization of mountain territories in the Middle Ages, by combining several types of written sources. Her work pays particular attention to the articulation between landed property, natural resources, and organization of peasant communities.

Marc Conesa (Ph.D. 2010, University of Montpellier) is an Associate Professor in Early Modern History in the University of Montpellier (Laboratory CRISES). His research explores the relationships between societies and territories in Pyrenees and Mediterranean area.

Delphine Bousquet (M.A. 2008) is a Ph.D. student at the Ecole des Hautes Etudes en Sciences Sociales in Toulouse. Her research focuses on the construction of Bronze and Iron Age landscapes with a special attention to the spatial analysis of artifacts from surface surveys and to the excavation of agrarian features. She has codirected the excavations of the Eyne and Llo sites with Pierre Campmajo since 2009.

Véronique Lallemand (M.A. 2005, University of Perpignan) is an archaeologist of the Middle Ages, with a special interest in mountain occupation. As a researcher with the regional Archaeology Department of the Languedoc-Roussillon (French Ministry of Culture), she guided and supervised the evaluation of Vilalta. She is also coordinating a research program on the conservation of rocks engravings in the Cerdagne.

\section{References}

Acabado, S. 2010. The Archaeology of the Ifugao Agricultural Terraces: Antiquity and Social Organization. Ph.D. dissertation, University of Hawai' i at Manoa. ProQuest Dissertations and Theses.

Alart, B. 1874. Privilèges et titres relatifs aux franchises, institutions et propriétés communales de Roussillon et de Cerdagne, depuis le XIe siècle jusqu' à l' an 1660. Perpignan: Charles Latrobe.

Bal, M. C. 2006. "Constructions et dynamiques des espaces et des terrasses agro- pastoraux en zone intermédiaire des Pyrénées du Néolithique à nos jours (Cerdagne, PaysBasque et Pays de Sault), approche archeéoenvironnementale par la pédoanthracologie." Unpublished Ph.D. dissertation, University of Toulouse-Le-Mirail, Toulouse, France.

Bal, M. C., C. Rendu, M. P. Ruas, and P. Campmajo. 2010. "Paleosol Charcoal: Reconstructing Vegetation History in Relation to Agro-pastoral Activities Since the Neolithic. A Case Study in the Eastern French Pyrenees," Journal of Archaeological Science 37: 1785-1797.

Ballesteros Arias, P. 2006. "Formas y fechas de un paisaje agrario de época medieval: a Cidade da Cultura en Santiago de Compostela," Arqueología Espacial 26: 193-225.

Ballesteros Arias, P. 2010. "La arqueología rural y la construcción de un paisaje agrario medieval: el caso de Galicia," in H. Kirchner, ed., Por una arqueología agraria. Perspectivas de investigación sobre espacios de cultivo en las sociedades medievales hispánicas. BAR International Series 2062. Oxford: B.A.R., 25-39.

Batlle, M., and R. Gual. 1973. "Fogatges catalans, recensements du XIe au XXe siècle," Terra nostra 11: 1-88.

Bevan, A., J. Conolly, S. Colledge, C. Frederick, C. Palmer, R. Siddall, and A. Stellatou. 2013. "The Long-term Ecology of Agricultural Terraces and Enclosed Fields from Antikythera, Greece," Human Ecology 41: 255-272.

Bille, E. 2004. "Seigneurs, maisons et vacants. La Cerdagne du Xe au XIVe siècle." Unpublished Ph.D. dissertation, University of Toulouse-Le-Mirail, Toulouse, France.

Boissinot, P. 2000. 'A la trace des paysages agraires. L' archéologie des façons culturales en France," Etudes rurales 153/154: 23-38.

Borejsza, A., I. Rodríguez López, C. D. Frederick, and M. D. Bateman. 2008. "Agricultural Slope Management and Soil Erosion at La Laguna, Tlaxcala, Mexico," Journal of Archaeological Science 35: 1854-1866.

Bosom, S., and S. Vela. 2009. Llibre de les provisions reials de la vila de Puigcerdà. Fundacio Noguera Llibres de Privilegis 14. Barcelona: Fundacio Noguera.

Bousquet, D. 2011. "Contribution à l' étude des anciens paysages agropastoraux de montagne. Le cas de la commune d' Eyne en Cerdagne (Pyrénées-Orientales)," in J. R. Trochet, ed., Le paysage d'aujourd' hui à hier, d' hier à aujourd' hui. Paris: CTHS, édition électronique, 5-24.

Bousquet, D., P. Campmajo, D. Crabol, and C. Rendu. 2014. "Evolution de la poterie du Bronze moyen au Bronze final. Eléments pour une chronologie de l' anthropisation d' un espace montagnard (Cerdagne, Pyrénées-Orientales)," Documents d' archéologie méridionale. Protohistoire du Sud de la France 35: 151-174.

Bréhard, S., and P. Campmajo. 2005. "Exploitation des animaux domestiques et structuration de l' espace montagnard à l' Âge du Bronze: Llo (Cerdagne, Pyrénées-Orientales)," Anthropozoologica 40(1): 217-233.

Calvet, M., and Y. Gunnell. 2008. "Planar Landforms as Markers of Denudation Chronology: An Inversion of East Pyrenean Tectonics Based on Landscape and Sedimentary Basin Analysis," in K. Gallagher, S. J. Jones and J. Wainwright, eds., Geological Society, London, Special Publications 296. London: Geological Society, 147-166. 
Campmajo, P. 1979. Rapport d' intervention archéologique, commune de Targasonne, Clot de Vilalte, Montpellier: Direction des Antiquités du Languedoc Roussillon.

Campmajo, P. 1983. Le site protohistorique de Llo, Travaux de préhistoire catalane 2. Perpignan' Centre d' Etudes Préhistoriques Catalanes, Université de Perpignan.

Campmajo, P. 1991. "El poblament de la Cerdanya des dels origens a l' occupació romana," Ceretania 1: 21-38.

Carozza, J. M., C. Puig, T. Odiot, O. Passarrius, and P. Valette. 2011. "Lower Mediterranean Plain Accelerated Evolution During the Little Ice Age: Geoarchaeological Insight in the Tech Basin (Roussillon, Gulf of Lion, Western Mediterranean)," Ouaternarv International 266: 94-104.

Conesa, M. 2012. D' herbe, de terre et sang. La Cerdagne du XIVe au XIXe siècle. Perpignan: Presses Universitaires de Perpignan.

Davasse, B., D. Galop, and C. Rendu. 1997. "Paysages du Néolithique à nos jours dans les Pyrénées de l' Est d' après l' écologie historique et l' archéologie pastorale," in J. Burnouf, J. P. Bravard and G. Chouquer, eds., La dynamique des paysages protohistoriques, antiques, médiévaux et modernes, $X$ VIIe rencontres internationales d' archéologie et d' histoire d' Antibes. Sophia Antipolis: Editions APDCA, 577-599.

Davidovich, U., N. Porat, Y. Gadot, Y. Avni, and O. Lipschits. 2012. "Archaeological Investigations and OSL Dating of Terraces at Ramat Rahel, Israel," Journal of Field Archaeologv 37(3): 192-208.

Delmas, M., M. Calvet, and Y. Gunnell. 2009. "Variability of Quaternary Glacial Erosion Rates-A Global Perspective with Special Reference to the Eastern Pyrenees," Ouaternary Science Reviews 28: 484-498.

Frederick, C., and A. Krahtopoulou. 2008. "The Stratigraphic Implications of Long-term Terrace Agriculture in Dynamic Landscapes: Polycyclic Terracing from Kythera Island, Greece," Geoarchaeology 23: 550-585.

Galop, D. 1998. La forêt, l' homme et le troupeau dans les Pyrénées, 6000 ans d' histoire de l' environnement entre Garonne et Méditerranée. Toulouse: Méridiennes.

Galop, D. 2006. "La conquête de la montagne pyrénéenne au Néolithique. Chronologie, rythmes et transformations des paysages à partir des données polliniques," in J. Guilaine, ed., Populations néolithiques et environnement. Paris: Errance, 279-295.

Galop, D., L. Carozza, F. Marembert, and M.C. Bal. 2007. "Activités pastorales et climat durant l' âge du Bronze dans les Pyrénées: 1' état de la question à la lumière des données environnementales et archéologiques," in H. Richard, ed., Environnements et cultures à l' âge du Bronze en Europe occidentale. Paris: CTHS, 107-119.

Gassiot, E., N. Mazzuco, I. Clemente, and D. Rodriguez Anton. 2012. "Circulación e intercambio en el poblamientoy la explotación de la alta montaña del pirineo en los milenios V-IV ane," Rubricatum 5: 61-68.

Harfouche, R. 2005. "Retenir et cultiver le sol sur la longue durée: les terrasses de culture et la place du bétail dans la montagne méditerraneenne," Anthropozoologica 40: 45-80.

Harfouche, R. 2007. Histoire des paysages méditerranéens terrassés: aménagements et agriculture. BAR International Series 1634. Oxford: B.A.R.

Kemp, R., N. Branch, B. Silva, F. Meddens, A. Williams, A Kendall, and C. Vivanco. 2006. "Pedosedimentary, Cultural and Environmental Significance of Paleosols within Pre-hispanic Agricultural Terraces in the Southern Peruvian Andes,' Ouaternary International 158: 13-22.

Kotarba, J., C. Jandot, C. Rendu, and P. Campmajo. 2007. "Le Pla de la Creu à Bolquère," Bilan scientifique du service régional de l' archéologie Languedoc-Roussillon. Montpellier: Ministère de la Culture: 202-203.

Marca, P. de. 1688. Marca hispanica sive limes hispanicus Paris: Franciscum Muguet [fac-simile Barcelone, Editorial Base, 1998

Martzluff, M. 1998. 'L' habitat protohistorique et médiéval du Veïnat de Dalt, à Targasonne (Cerdagne)," Comerc i vies de comunicacio (1000 aC- 700 dC). XIe Colloqui internacional d' arqueologia de Puigcerdà. Puigcerdà: Institut d' Estudis Ceretans: 421-433.

Martzluff, M. 2009."Au temps des pierres amoureuses. Typologie du débitage des roches monumentales depuis l' an mil dans les Pyrénées Catalanes," De Méditerranée et d' ailleurs: mélanges offerts à Jean Guilaine. Toulouse: Archives d' Ecologie Préhistorique: $483-508$.
Maurel, O., M. Brunel, and P. Monié. 2002. "Exhumation cénozoïque des massifs du Canigou et de Mont-Louis (Pyrénées orientales, France)," Comptes Rendu Geoscience 334: 941-948.

Orengo, H. A, J. M. Palet, A. Ejarque, Y. Miras, and S. Riera. 2014. "Shifting Occupation Dynamics in the Madriu Perafita Claror Valleys (Andorra) from the early Neolithic to the Chalcolithic: The Onset of High Mountain Cultural Landscapes," Ouaternarv International 353(5): 140-152.

Passarrius, O., R. Donat, and A. Catafau. 2008. Vilarnau: un village du Moyen Âge en Roussillon. Canet: Trabucaire.

Quiros Castillo, J.-A. 2009. "Arqueologia de los espacios agrarios medievales en el Pai's Vasco," Hispania, revista española de Historia 69: 619-659.

Reimer, P. J., M. G. L. Baillie, E. Bard, A. Bayliss, J. W. Beck, P. G. Blackwell, C. Bronk Ramsey, C. E. Buck, G. S. Burr, R. L. Edwards, M. Friedrich, P. M. Grootes, T. P. Guilderson, I. Hajdas, T. J. Heaton, A. G. Hogg, K. A. Hughen, K. F. Kaiser, B. Kromer, F. G. McCormac, S. W. Manning, R. W. Reimer, D. A. Richards, J. R. Southon, S. Talamo, C. S. M. Turney, J. van der Plicht, and C. E. Weyhenmeyer. 2009. "IntCa109 and Marine09 Radiocarbon Age Calibration Curves, 0-50,000 Years cal bp," Radiocarbon 51: 1111-1150.

Rendu, C. 2001. "Fouiller des cabanes de bergers: pour quoi faire ?' in J. Guilaine, ed., La très longue durée, Etudes Rurales 153 154: $151-176$.

Rendu, C. 2003. La montagne d'Enveig, une estive pyrénéenne dans la longue durée. Canet: Trabucaire.

Rendu, C., P. Campmajo, and D. Crabol. 2012. "Etagement, saisonnalité et exploitation des ressources agro-pastorales en montagne à l' âge du bronze. Une possible 'ferme d' altitude' à Enveig (Pyrénées-Orientales)," Bulletin de l'Association pour la Recherche sur l' Âge du Bronze 10: 58-61.

Riera, S., and J. M. Palet. 2008. "Una aproximación multidisciplinar a la historia del paisaje mediterráneo: La evolución de los sistemas de terrazas con muros de piedra seca en la sierra de Marina (Badalona, Llano de Barcelona)," in R. Garrabou and J. M. Nareda, eds., El paisaje en perspectiva histórica. Formación y transformación del paisaje en el mundo mediterráneo. Monografias de Historia Rural 6. Zaragoza: Prensas Universitarias de Zaragoza, 47-90.

Roose, E., and M. Sabir. 2002. "Stratégies traditionnelles de conservation de l' eau et des sols dans le bassin méditerranéen: classification en vue d' un usage renouvelé," in E. Roose, M. Sabir and G. De Noni, eds., "Techniques traditionnelles de GCES en milieu méditerranéen," Bulletin du Réseau Erosion 21: $33-44$.

Ruas, M.-P., C. Rendu, and A. Bergeret. 2005. "Glanes et cultures médiévales en haute montagne. Réflexions autour d' une cabane d' estive à Enveig et du château des Angles (Pyrénées-orientales)", in A. Catafau, ed., Les ressources naturelles des Pyrénées du Moyen Âge à l'Époque moderne. Exploitation, gestion, appropriation. Perpignan: Presses Universitaires de Perpignan, 147-184.

Ruas, M.-P., L. Bouby, and P. Campmajo. 2009. "Agriculture en montagne cerdane au Bronze final: les données carpologiques de Llo-Lo Lladre (Pyrénées-Orientales)," De Méditerranée et d' ailleurs: mélanges offerts à Jean Guilaine. Toulouse: Archives d' Ecologie Préhistorique: 639-660.

Ruas, M.-P., C. Rendu, and A. Bergeret. 2005. "Glanes et cultures médiévales en haute montagne. Réflexions autour d' une cabane d' estive à Enveig et du château des Angles (Pyrénées-orientales), " in A. Catafau, ed., Les ressources naturelles des Pyrénées du Moyen Âge à l'Époque moderne. Exploitation, gestion, appropriation. Perpignan, France: Presses Universitaires de Perpignan, 147-184.

Sandor, J. A. 2006. "Ancient Agricultural Terraces and soils," in B. P. Warkentin, ed., Footprints in the Soil: People and Ideas in Soil History. Amsterdam: Elsevier, 505-534.

Sandor, J. A., and N. S. Eash. 1991. "Significance of Ancient Agricultural Soils for Long-term Agronomic Studies and Sustainable Agriculture Research," Agronomic Journal 83: 29-37.

Sandor, J. A., and N. S. Eash. 1995. "Ancient Agricultural Socials in the Andes of Southern Peru," Soil Science Society of American Journal 59: 170-179.

Schwartz, D., L. Bernardy, C. Jouve-Litaudon, and A. Vonna. 2003. 'Le Bickenberg à Osenbach (Haut-Rhin). Etude d' un paysage d' enclos médiéval sur les collines calcaires sèches sous-vosgiennes," Revue Géographique de l' Est 43(3): 2-19.

Vaquer, J. 1976. "Gisements néolithiques en Cerdagne," Cypsela 1: $36-38$ 